\title{
Utilizing the Hippo pathway as a therapeutic target for combating endocrine-resistant breast cancer
}

\author{
Jing Chen ${ }^{1,2}$, Runlan Wan ${ }^{1}$, Qinqin $\mathrm{Li}^{1,2+}$, Zhenghuan Rao ${ }^{1,2+}$, Yanlin Wang ${ }^{3 \dagger}$, Lei Zhang ${ }^{4 \dagger}$ and \\ Alexander Tobias Teichmann ${ }^{1,2^{*}}$ (1)
}

\begin{abstract}
Drug resistance is always a great obstacle in any endocrine therapy of breast cancer. Although the combination of endocrine therapy and targeted therapy has been shown to significantly improve prognosis, refractory endocrine resistance is still common. Dysregulation of the Hippo pathway is often related to the occurrence and the development of many tumors. Targeted therapies of this pathway have played important roles in the study of triple negative breast cancer (TNBC). Targeting the Hippo pathway in combination with chemotherapy or other targeted therapies has been shown to significantly improve specific antitumor effects and reduce cancer antidrug resistance. Further exploration has shown that the Hippo pathway is closely related to endocrine resistance, and it plays a "co-correlation point" role in numerous pathways involving endocrine resistance, including related pathways in breast cancer stem cells (BCSCs). Agents and miRNAs targeting the components of the Hippo pathway are expected to significantly enhance the sensitivity of breast cancer cells to endocrine therapy. This review initially explains the possible mechanism of the Hippo pathway in combating endocrine resistance, and it concludes by recommending endocrine therapy in combination with therapies targeting the Hippo pathway in the study of endocrine-resistant breast cancers.
\end{abstract}

Keywords: Hippo pathway, Breast cancer, Endocrine therapy, Endocrine resistance, Breast cancer stem cells, MicroRNA

\section{Introduction}

The incidence of breast cancer ranks first among all female malignancies [1]. Most breast cancers are surely estrogen receptor-positive $(E R+)$ and can depend on estrogen for tumor cell growth. The major treatment strategy for endocrine therapies focused on ER + breast cancer is estrogen deprivation. The current drugs to this end can be classed as aromatase inhibitors, selective

\footnotetext{
*Correspondence: alexandertobiasteichmann@swmu.edu.cn

${ }^{\dagger}$ Qinqin Li, Zhenghuan Rao, Yanlin Wang and Lei Zhang contributed equally to the paper

${ }^{1}$ Department of Gynaecology and Obstetrics, The Affiliated Hospital of Southwest Medical University, No. 25 Taiping Street, Jiangyang District, Luzhou 646000, People's Republic of China

Full list of author information is available at the end of the article
}

estrogen receptor degraders, and selective estrogen receptor modulators. However, about one-third of patients still develop recurrence after long-term endocrine therapy [2]. Drug resistance to endocrine therapy has become a pivotal obstacle to treatment, although endocrine therapy is effective in reducing mortality and improving survival rates [3]. The reasons for drug resistance are multiple and complex, and they involve various molecules. Currently, targeted therapies combined with endocrine therapy have been shown to be effective for combating endocrine resistance, as illustrated in Table 1, which includes targets of Cyclin-dependent kinases (CDKs) 4 and 6, mammalian targets of rapamycin (mTOR) and phosphoinositide 3-kinase (PI3K). Their combination as first or second-line treatments for 
hormone receptor-positive metastatic breast cancer has been recommended by AMA guidelines, which was corroborated by a network meta-analysis [4]. Unfortunately, the combination of CDK 4 and 6 inhibitors still does not completely overcome drug resistance $[5,6]$. The Hippo pathway, a newly targeted pathway, has been found to be related to multiple malignancies and modulation of this pathway may be able to effectively overcome endocrine resistance. In this review, the therapeutic potential of the Hippo pathway in the promotion of endocrine therapy is

Table 1 Targeted agents approved for combination with endocrine therapy for the treatment of breast cancer

\begin{tabular}{|c|c|c|c|}
\hline Targets & Agents & Mechanism & References \\
\hline mTOR & Everolimus & $\begin{array}{l}\text { Generates a complex that } \\
\text { inhibits the activation of } \\
\text { mTOR }\end{array}$ & {$[7]$} \\
\hline \multirow[t]{3}{*}{ CDK4/6 } & Palbociclib & \multirow{3}{*}{$\begin{array}{l}\text { Inhibits CDK4/6, allowing } \\
\text { restoration of control of } \\
\text { cell cycle }\end{array}$} & {$[8]$} \\
\hline & Ribociclib & & [9] \\
\hline & Abemaciclib & & [10] \\
\hline PI3K & Alpelisib & Specifically inhibits PI3Ka & {$[11]$} \\
\hline
\end{tabular}

CDK cyclin-dependent kinase, mTOR mammalian target of rapamycin, $P I 3 K$ phosphoinositide 3-kinase addressed, which provides theoretical references for the design of further studies and clinical consequences.

\section{Mechanism of endocrine resistance in breast carcinoma}

The complex reasons of endocrine resistance involves the estrogen receptor (ER) pathway, the growth factor receptor (GFR) pathways, and the CDK 4 and 6 pathway, as well as epigenetic modification. In recent years, the interdependence between BCSCs and drug resistance has emerged, and it often involves BCSC-related pathways, offering new insight into endocrine resistance.

\section{Refractory resistance facilitated by escaped BCSCs}

BCSC-related markers, such as $\mathrm{CD} 44^{+} \mathrm{CD} 24^{-/ \text {low }}$ [12], ALDH [13], CD133 [14],Nanog [15], Sox2 [12], and Sox9 [16], were found to be enriched or positive in tamoxifenresistant [12-16], letrozole-treated [17], and fulvestranttreated cells [18]. The proportion of cells bearing stem cell markers in resistant cell line stronger increased than that of non-resistant [12]. On the one hand, dormant and self-renewal deficient BCSC populations are generated during long-term endocrine therapy, leading to endocrine resistance after these cells exit from metabolic

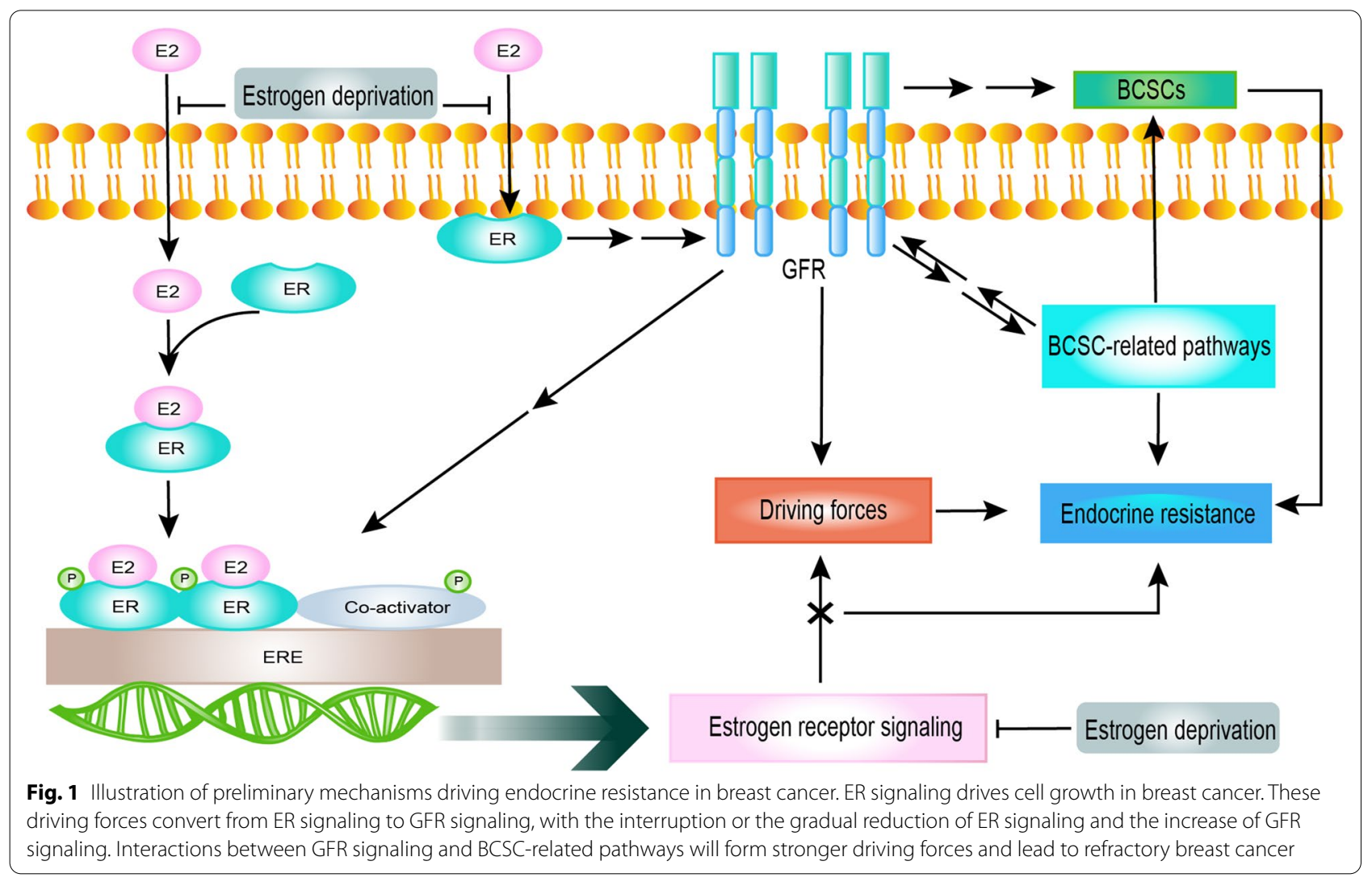




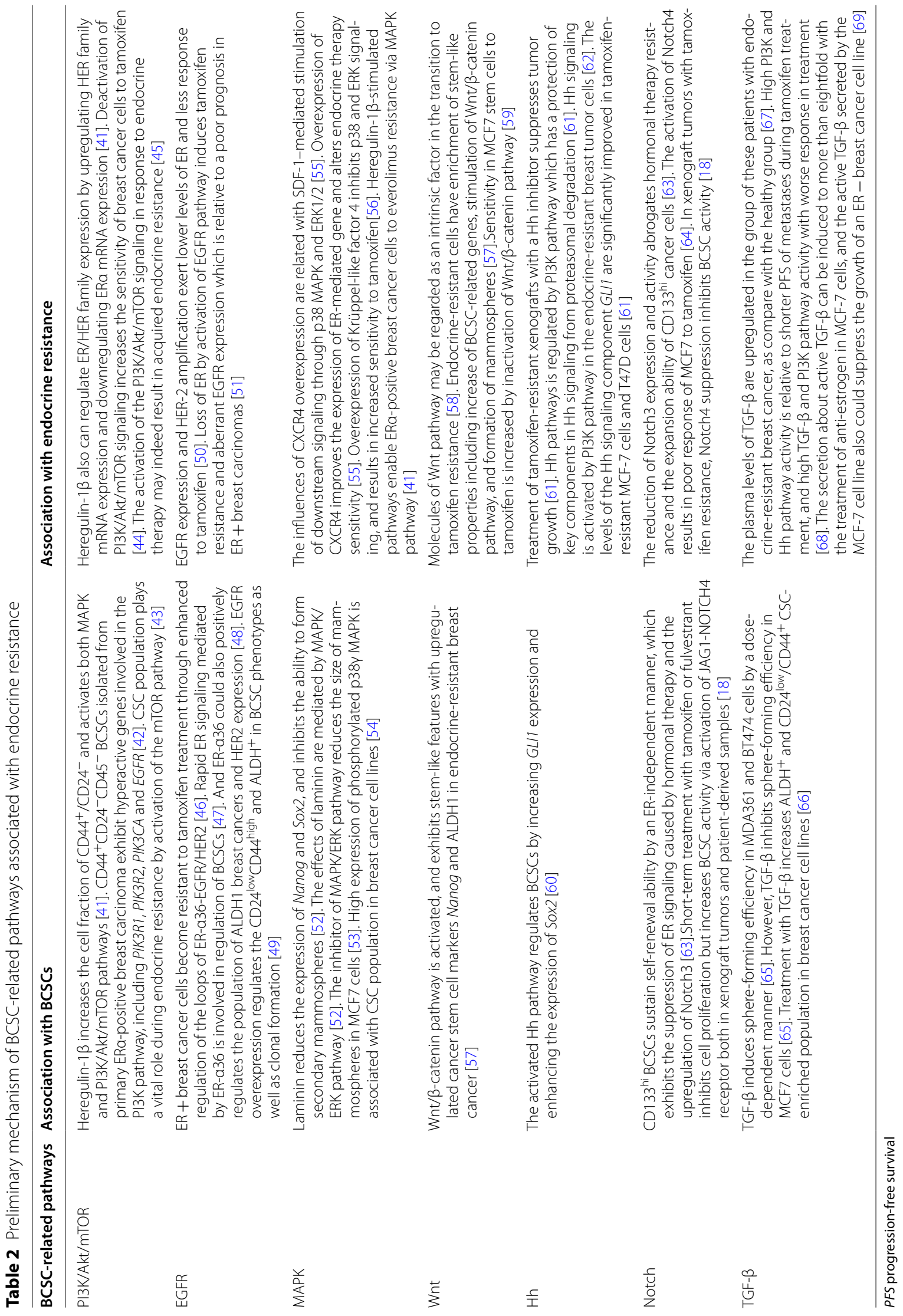




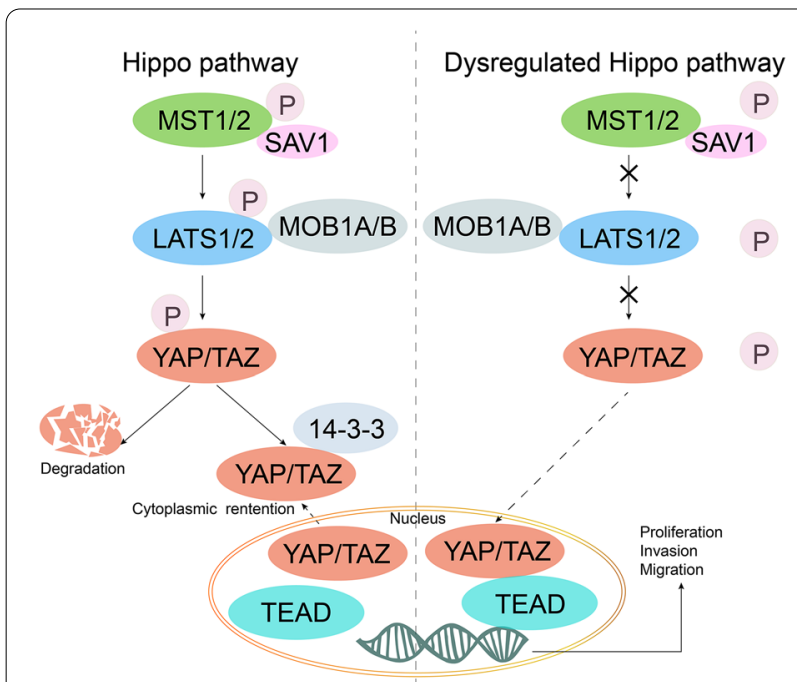

Fig. 2 Illustration of the canonical Hippo pathway and its dysregulation. MST1/2 and LATS1/2 are kinases. SAV1 (WW45) and $\mathrm{MOB} 1 \mathrm{~A} / \mathrm{B}$ are adaptors. The phosphorylation cascade in the Hippo pathway can negatively regulate YAP/TAZ and inhibit the proliferation-promoting effects of YAP/TAZ. Dysregulation leads to proliferation, invasion, and migration of malignancies via the nuclear translocation of YAP and TAZ

dormancy [19]. On the other hand, ER activity affects the enrichment of BCSCs via mutations in the ESR1 gene (estrogen receptor-gene), including Y537N, Y537S, and D598G, which are involved in ligand-independent activation of ER [20]. Moreover, ER- $\alpha 36$ [21], ER $\beta$ [22], and G protein-coupled estrogen receptor (GPER) [23] are all involved in the promotion or maintenance of breast cancer stem cell character. Moreover, BCSC populations are considered to be estrogen receptor negative $(E R-)$ and can regulate ER expression [24, 25], giving them the ability to generate ER + cells [26] or differentiate into cells that have lost ER $\alpha$ expression [27]. Therefore, the core reason for drug resistance is the stem cell behavior of breast cancers.

\section{The interaction between ER signaling, GFR signaling, and BCSC-related pathways}

BCSC-related pathways include the Hippo pathway, and those that signal via Hedgehog (Hh) signaling, transforming growth factor $\beta$ (TGF- $\beta$ ) signaling, Notch signaling, PI3K/Akt/mTOR pathway, Wnt pathway, epidermal growth factor receptor (EGFR) pathway, ER signaling, and mitogen-activated protein kinase (MAPK) pathway. GFR signaling includes human epidermal growth factor receptor 2 (HER2) signaling, fibroblast growth factor receptor 1 (FGFR) signaling, and PI3K/Akt pathway, and they are three BCSC-related pathways. And other GFR signaling pathways are insulin-like growth factor 1 receptor (IGF-1R) signaling, MAPK signaling, and EGFR pathway. ER signaling is considered to be the main source of driving forces for the growth of ER+breast carcinomas. Changes in ER signaling are the first step for acquiring endocrine resistance, and this can include downregulation of ER $\alpha$ expression or loss of ER $\alpha$ expression caused by mutation or methylation of ER $\alpha$-related genes [28]. These driving forces convert from ER signaling to GFR signaling [29, 30], as described in Fig. 1. The cross talk between GFR signaling and BCSC-related pathways may be the next step that leads to refractory resistance $[28,31,32]$. The preliminary relationship between part of BCSC-related pathways and endocrine resistance is diverse and complex, as illustrated in Table 2. And several signaling pathways of GFR are also BCSC-related pathways in this table. This reveals the dual roles of PI3K/ Akt/mTOR, EGFR and MAPK pathways involve in endocrine resistance and breast cancer stem cell character. Moreover, it also reveals the extensive and complex role about BCSCs and BCSC-related pathways for endocrine resistance. BCSCs can depend on the GFR signaling pathway to survive, and escape from estrogen deprivation based on their ER - status [29, 33, 34]. Eventually, BCSCs will become the root cause of refractory resistance and escort breast cancers toward "permanent survival". The combinations of targeted therapies focused on IGF-1R [35], HER2 [36, 37], or epidermal growth factor receptor [38-40] and endocrine therapy, even dual-targeting therapies plus endocrine therapy, have been shown not to reverse endocrine resistance or significantly enhance the effects of endocrine therapy. It has been suggested that breast cancers can still maintain endocrine resistance through the synergy of other pathways after inhibiting a small portion of these pathways. In conclusion, the process of endocrine resistance in breast carcinomas is the synergy of multiple mechanism. A new solution needs to be conceived.

\section{The Hippo pathway}

The Hippo pathway is also called the Salvador/Warts/ Hippo pathway, and can precisely control the number of cells and stop organism growth in a timely manner during the development of mammals.

\section{Hippo pathway and its dysregulation}

When the phosphorylation cascades of the Hippo pathway become blocked, these cells will differentiate abnormally and gradually develop into malignancies [70]. Then, inhibited or disabled Hippo phosphorylation cascades of Hippo pathway will further facilitate the invasion and migration of tumor cells [71, 72]. The mechanism of the canonical Hippo pathway and its dysregulation is described in Fig. 2. The activated Hippo pathway 


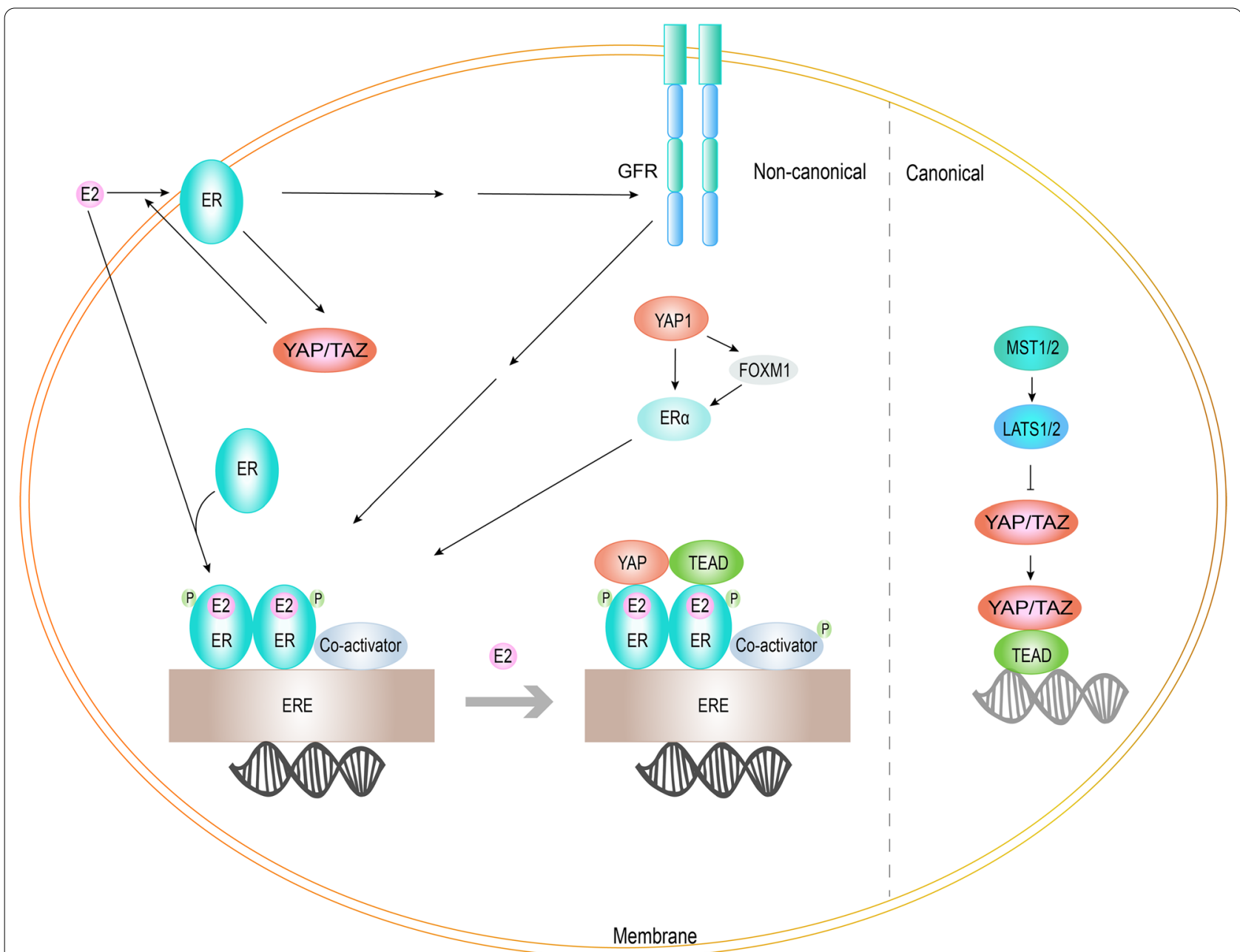

Fig. 3 Preliminary illustration of non-canonical roles between the Hippo pathway and ER signaling in breast cancer. Feedback was formed between YAP/TAZ and ER. YAP and TEAD function as co-regulators of ER signaling to facilitate gene transcription of ER signaling genes

participates in the reasonable regulation of apoptosis and cell growth, when transcriptional coactivator with PDZ-binding motif (TAZ), and homologous component the yes-associated protein (YAP) are inactivated via their phosphorylation cascade. A variety of upstream signals activate mammalian sterile20-like (MST) kinases, and then MST kinases phosphorylate large tumor suppressor (LATS) kinases [73]. The activated LATS1/2 kinases can change the status of the phosphorylation and distribution of YAP/TAZ [74] resulting in the arrest of the cell cycle [75, 76]. LATS [77] and MST [73] are considered to have antitumor effects, and play negative roles in the regulation of TAZ and YAP. The entry of phosphorylated YAP/TAZ into the nucleus is restricted, and YAP/TAZ will be degraded after transferring into the cytoplasm from the nucleus, which can turn off antiapoptotic gene transcriptions and the cell cycle progression [78]. Conversely, when the Hippo pathway is dysregulated, the expression of downstream target genes of the Hippo pathway will promote cell proliferation and inhibit apoptosis genes, facilitating malignancies [79]. Dysregulation of the Hippo pathway showed results in excessive activation [80] or increased nuclear localization of YAP/TAZ by relatively decreasing YAP/TAZ phosphorylation [81], inhibiting LATS [82] and MST [83, 84]. Therefore, activated YAP and homologous TAZ are the core regulators of this pathway, since both of them exert oncogenic roles $[85,86]$ in the presence of a dysregulated Hippo pathway. Moreover, the low expression of MST and LATS will lead to the loss of control of YAP and TAZ [87]. Beyond this, additional non-canonical roles of the Hippo pathway in breast cancer have gradually emerged in recent years. 


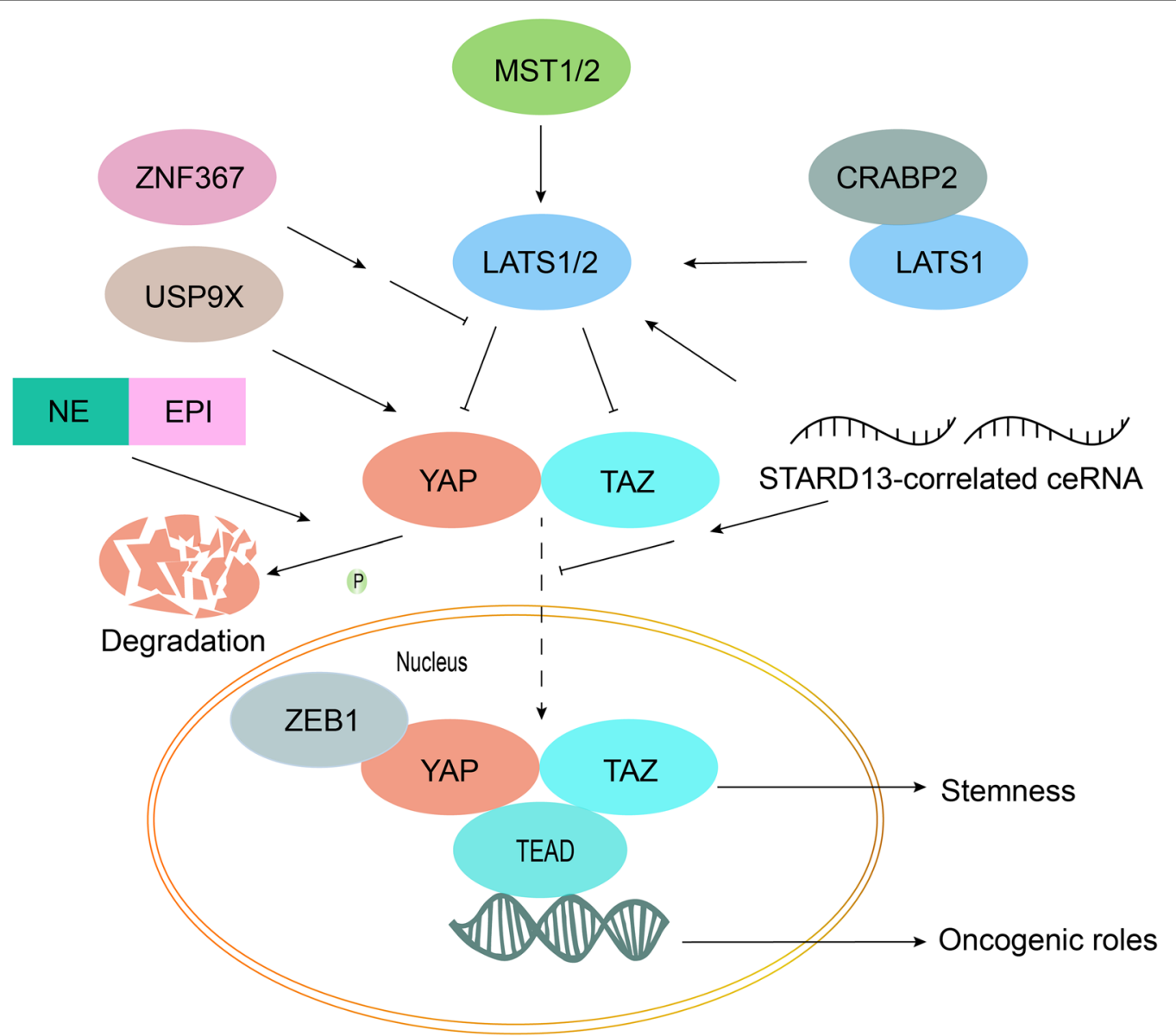

Fig. 4 Illustration of the roles of the Hippo pathway in ER + breast cancer. Overexpression of ZNF367 facilitates metastasis and activates Hippo/ YAP signaling by inhibiting LATS [110]. Overexpression of USP9X stimulates cell proliferation by deubiquitinating and stabilizing YAP1 [111]. NE and EPI suppress breast cancer via rapid phosphorylation and cytoplasmic retention of YAP [112]. ZEB1, a transcriptional activator, interacts with YAP1 and promotes transcription [113]. The interaction of LATS1 and CRABP2 inhibits the ubiquitination of LATS1 to suppress cell invasion [106]. The STARD13-correlated ceRNA network regulates TAZ distribution, and it can inhibit the stem cell character of breast cancer through upregulation of LATS1/2 [114]

\section{Breast cancer stem cell character suppression by the Hippo} pathway

It has been confirmed that TAZ, YAP, LATS, and TEA domain family members (TEAD) are involved in the regulation of BCSCs. Cordenonsi et al. [88] first linked the Hippo pathway to the concept of BCSC proliferation. Since then, studies have confirmed that BCSCs can be facilitated by TAZ [89-93]. YAP [94-97], as a homology of TAZ, the same as LATS [98] or TEAD [99], can also regulate BCSCs. Liu et al. [90] showed the restoration of sensitivity to tamoxifen and suppressed BCSCs by inhibiting TAZ expression. Moreover, dysregulation of the Hippo pathway is one of the prerequisites for the progress of an epithelial-mesenchymal transition (EMT) [100], which enables tumor to maintain the stem cell character [88]. MiR-520b activates the Hippo/YAP signaling pathways by targeting LATS, increasing the mRNA level of BCSC markers, such as CD133, CD44, and ALDH1, and the EMT marker N-cadherin in breast cancer [94]. Therefore, reactivating the Hippo pathway can effectively combat endocrine resistance and the expression of several oncogenes facilitated by BCSC transition.

\section{The cross talk between the Hippo pathway and multiple pathways involved in endocrine resistance}

Breast cancer can rely on ER signaling to promote cell proliferation, which is different from other tumors. The Hippo pathway is indeed associated with almost all pathways related to endocrine resistance, including ER signaling. Researchers have found partial cross talk between the Hippo pathway and ER signaling. Recent studies have found that targeting and activating the Hippo pathway 
can negatively regulate $\mathrm{BCSCs}$ and overcome endocrine resistance. Moreover, it also seems to be involved in the integration of GFR signaling pathways and Hippo pathway. This indicates that the Hippo pathway may make an unexpected contribution to endocrine therapy in $\mathrm{ER}+$ breast cancers.

\section{The correlation between the Hippo pathway and the ER signaling pathway}

Preliminary non-canonical roles between the Hippo pathway and ER signaling in breast cancer is described in Fig. 3. On the one hand, the non-canonical roles of the components in Hippo pathway play a vital role in the management of ER signaling. YAP1 and TEAD4, co-regulators of $E R \alpha$ on enhancers, are augmented upon estrogen stimulation and transduction of target genes of ER signaling [101]. In addition, the expression of ER $\alpha$ was shown to directly be increased by YAP1 or indirectly mediated by the fork head box protein M1 (FOXM1) in the absence of the tumor suppressor Ras-association domain family 1 [102]. YAP/TAZ have also been shown to mediate the process of target gene induction by GPER [103]. On the other hand, ER can also affect the Hippo pathway. A study on mouse morula and trophoblast stem cells found that the nuclear localization of YAP was indeed regulated by ER $\alpha$ [104]. Moreover, the invasion and migration of TNBC were inhibited when the nuclear localization of YAP was inhibited, while sometimes the same situation did not appear in ER + breast cancer, which may have been related to the compensatory increase in the nuclear localization of YAP mediated by ER [105]. The status of ER can also affect the interaction between cellular retinoic acid binding protein 2 (CRABP2) and LATS to regulate the Hippo pathway and modulate sensitivity to endocrine therapy [106]. Moreover, GPER facilitates the progression of breast cancer by activating YAP/TAZ [103]. A study of tumor breast (226 samples) and normal (40 samples) from microarray samples found that the level of YAP expression was evidently downregulated in invasive cancer samples compared to normal tissues samples, and decreased expression of YAP was remarkably associated with ER - status [107]. This suggested that invasive breast cancer cells with reduced expression of YAP were more likely to be ER - and may have an lower threshold for becoming resistant to endocrine therapy. Feedback regulation of hormone receptors on the Hippo pathway in turn was weakened by the downregulation of ER $\alpha$ expression, and also was decreased by downward fluctuation of YAP. It may be the explanation for the lower YAP levels in invasive breast cancer are relative to normal breast tissue. The non-canonical Hippo pathway can in turn act on ER receptors to antagonize endocrine therapy, which can eventually leads to driving forces for tumor growth conversion to GFR signaling after estrogen-deprivation therapy. The regulation of the Hippo pathway for breast cancers dependent on different ER status and the different stage of endocrine resistance may be different $[98,106]$. Thus, the study of the Hippo pathway in breast cancer cannot be generalized like other hormone-independent tumors.

\section{Antagonism of the Hippo pathway for endocrine resistance in $\mathrm{ER}+$ breast cancer}

Studies in the MCF7 cell line (ER-positive breast cancer) have confirmed that correcting dysregulation of the Hippo pathway is a feasible scheme to inhibit breast cancer and overcome acquired drug resistance. The roles of the Hippo pathway in ER + breast carcinoma are described in Fig. 4. In summary, YAP and TAZ surely are carcinogenic. Although the regulation of Hippo has been rarely studied in endocrine-resistant cells, the great prospect for modulation of the Hippo pathway has become an important research object. Zhou et al. [103] found that GPER's role in inducing endocrine resistance could be regulated by the Hippo pathway and found that TAZ was overexpressed in GPER ${ }^{\text {hi }}$ breast cells. GPER activated YAP/TAZ, suggesting that blockage of GPER by knockdown of YAP/TAZ was a great strategy for overcoming tamoxifen resistance in GPER ${ }^{\text {hi }}$ breast cancers. Moreover, Zheng et al. [108] found that the YAP-glycolysis axis was also a target for overcoming tamoxifen resistance, based on the fact that the Hippo pathway was downstream of GPER. Li et al. [109] confirmed that downregulated YAP phosphorylation and upregulated YAP nuclear translocation directly resulted in tamoxifen resistance, which was reversed by YAP silencing.

\section{Cross talk between the Hippo pathway and BCSC-related pathways}

The Hippo pathway plays a "co-correlation point" role in several networks of BCSC-related pathways, including Notch, Wnt, EGFR, PI3K/Akt, MAPK/ERK1, Hh/ GLI2,TGF- $\beta$ pathway. Clara et al. [85] first proposed that the Hippo pathway may be the "hub" of cancer stem cell related pathways. The cross talk between Hippo and BCSC-related pathways except ER signaling has been shown as described in Fig. 5. Hippo pathway does crosstalk these seven pathways, and there forms "bridges" between Hippo, Wnt, EGFR and PI3K/Akt pathways through WBP2. And these "bridges" do enable GFR signaling pathways and BCSC-related pathways to form crosstalk. Extensive integration and local interlinkages reveal the advantages of Hippo pathway in regulation of drug resistance through breast cancer stem cell character. In addition, Hippo, TGF- $\beta$, Hh, MAPK, Wnt, PI3K/Akt, Notch, EGFR, and ER signaling were all associated with 
the EMT process. It has been further revealed that these pathways facilitate the synergistic regulation of breast cancer and can cause endocrine resistance in breast cancer. It is of no doubt, then, that the dysregulation of the Hippo pathway indeed facilitated the progression of breast cancer, and exert intricate cross talk on BCSCrelated pathways. BCSCs are the key to maintaining refractory survival and drug resistance for tumor cells, which is based on the coregulation of these pathways. Therefore, the "co-correlation point" role of the Hippo pathway in BCSC-related pathways may highlight a new solution for overcoming endocrine resistance.

\section{The interrelation between the Hippo pathway, GFR,} and the Cyclin-dependent kinase 4 and 6 pathways

The rest of GFR signaling pathways and Cyclin-dependent kinase 4 and 6 pathways involved in endocrine resistance also exert cross talk on the Hippo pathway. With regards to patients with luminal B subtypes, samples with low TAZ resulted in higher pathological complete response rates after trastuzumab-based neoadjuvant therapy, suggesting that HER2 linked with TAZ expression in a consistent manner [126]. YAP/TAZ dephosphorylation and overexpression increased in trastuzumab-resistant breast cancer cells, suggesting that the dysregulated Hippo pathway further facilitated cancer cells in coordination with HER2 [127]. Inhibiting YAP and TAZ could eliminate Lapatinib resistance, suggesting that dual target therapy for HER2 and the Hippo pathway had good prospects [128]. The Hippo pathway mediated FGFR signaling, the MAPK pathway, and PI3K signaling during tumorigenesis, and YAP/TAZ were shown to be possible therapeutic targets in RTK-driven cancers [129]. The phosphorylation of MST1 depended on the activity of fibroblast growth factor receptor 4 kinase. Moreover, short-term suppression or knockdown of FGFR4 led to increased activation of MST1/2 [130]. The IGF-1R/ YAP axis has been shown to be involved in the growth of TNBC [131]. Dysregulation of the Hippo pathway also can increase resistance to CDK4/6 inhibitors through accumulation of TAZ and YAP transcription factors on the promoter of Cyclin-dependent kinase 6 [5]. These studies further demonstrated the great potential of the Hippo pathway for remedying breast cancer.

\section{Integration of Hippo pathway in complex mechanism of endocrine resistance}

These roles of Hippo pathway in the integration of ER signaling are unique to breast cancers. The regulation of Hippo pathway on cancer stem cells is also affirmed, including BCSCs. Hippo pathway can not only combat BCSCs, but also can integrate these multiple pathways involve in endocrine resistance, including GFR (PI3K/Akt/mTOR, EGFR, MAPK, HER2, IGF-1R and FGFR),BCSC-related pathways (Wnt, PI3K/Akt/mTOR, Hh, EGFR, Notch, MAPK, TGF- $\beta$, ER), and CDK4/6 pathway. The "co-correlation point" role of Hippo pathway in the multiple mechanism of endocrine resistance as described in Fig. 6. To sum up, utilizing the Hippo pathway as a therapeutic target for combating endocrineresistant breast cancer may be a promising approach.

\section{Agents and miRNAs for research proposals focusing on the Hippo pathway}

In the process of endocrine therapy, the main driving forces for tumor growth were related to GFR signaling and even BCSC-related pathways. A dysregulated Hippo pathway did exert cross talk on these endocrine resistance-related pathways. A new therapeutic scheme that could be proposed to combat the "co-correlation point" of these pathways would focus on targeting the Hippo pathway. The combination of endocrine therapy and targeted therapy focusing on the Hippo pathway is expected to significantly improve the prognosis of patients with ER+ breast cancers. There are many agents that can target the Hippo pathway, including

\footnotetext{
(See figure on next page.)

Fig. 5 Illustration of the crosstalk of the Hippo pathway and BCSC-related pathways. Linc-OIP5 promotes transcription via forming a positive feedback circuit between YAP and Notch signaling [115]. IMP3 indirectly promotes Wnt5B via miR145-5p and facilitates TAZ-driven gene expression [116]. YAP and TAZ can promote the Wnt/ $\beta$-catenin/TCF axis and induce target genes by interaction with $\beta$-catenin, while WBP2 integrates the Hippo, Wnt, and PI3K pathway [117-119]. Mir-613 inhibits EGFR via directly inhibiting WBP2 and positive correlation of EGFR and WBP2 is confirmed, while EGFR promotes WBP2 phosphorylation, contributing to integration of the Wnt/ß-catenin and Hippo pathways [118, 119]. YAP/ TAZ mediate the synergistic function and oncogene expression induced by the PI3K and dysregulated Hippo pathways [120]. The MAPK/ERK1 pathway negatively regulates breast cancer proliferation by inhibiting YAP/TEAD [121]. YAP induces gene transcription and promotes glycolysis by wiring up the Hh/GLI2 axis [108]. The SnoN oncoprotein exerts negative feedback regulation on TGF- $\beta$ signaling, while promoting TAZ signaling and enhancing gene transcription in breast cancers [122]. Zyxin forms a ternary complex with LATS and Siah, which facilitates the degradation of LATS, activation of YAP and subsequently cell proliferation [123]. The tumor suppressor Merlin can inhibit YAZ/TAZ and maintain Smad7 stability, suppressing the adaptive glycolysis facilitated by the interaction between YAP/TAZ and Smads [124]. Ski inhibits breast cancer by suppressing TAZ in a LATS-dependent manner or in a LATS-independent manner, in which NCOR1 is recruited by Ski and suppresses TAZ by binding to the TEAD-TAZ complex [125]
} 


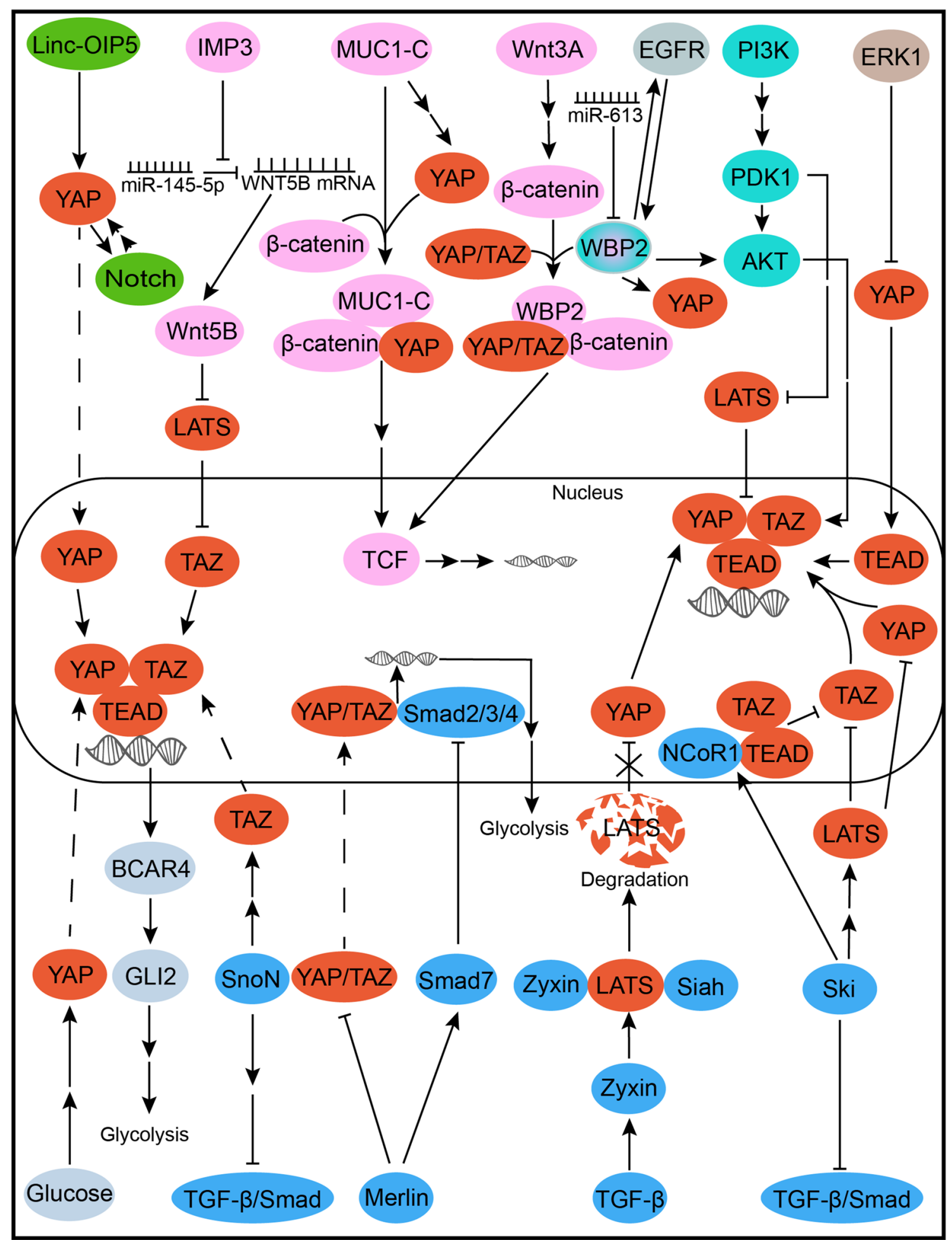




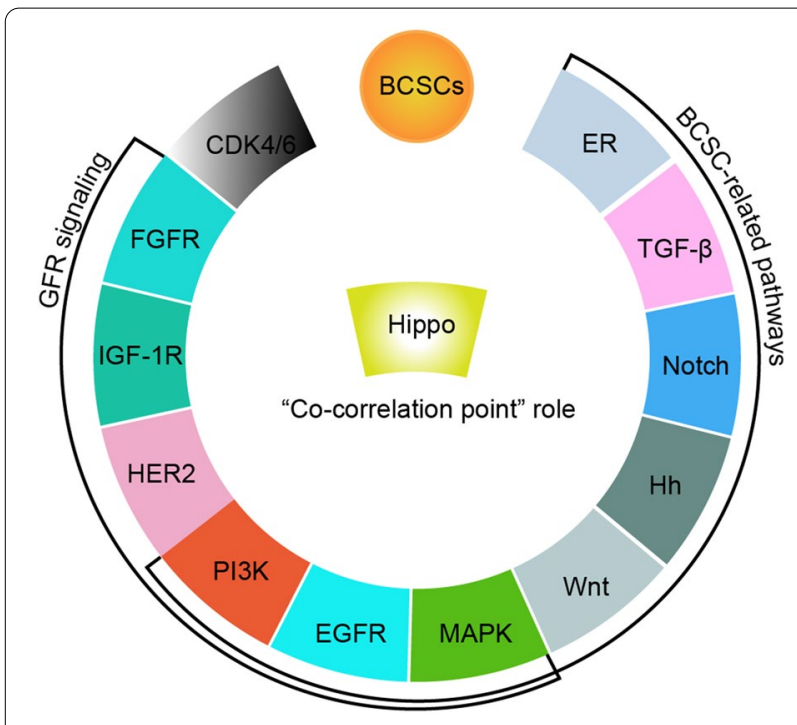

Fig. 6 Illustration of the "co-correlation point" role of Hippo pathway in the multiple mechanism of endocrine resistance them, although no available results. Clinical trials are designed for targeting the Hippo pathway as illustrated in Table 3. Clinical trials of combination of endocrine therapy and agents targeting Hippo pathway for reference as illustrated in Table 4. Moreover, the regulation of miRNAs is also an alternative tool. MiRNAs are related to the Hippo pathway in breast cancers, as illustrated in Table 5 and Fig. 7. Partial miRNAs can also be involved in the regulation of EMT [94, 133-135] and the maintenance of stem cell character in breast cancer [94, 134, 135]. MiR-125a-5p [136], the miR-200 family [137], miR-375 [138], and miR-181b [139], have all been recommended as therapeutic agents, since all of them can regulate endocrine resistance and were confirmed to be related to the Hippo pathway in other tumors. Upregulation of miR-125a-5p in tamoxifen resistant MCF7 cells may inhibit the growth of BCSCs by suppression of TAZ, which is an effective promoter of BCSCs. It is expected that the results of preclinical and clinical data will confirm its role in the future.

\section{Conclusion and prospects}

Targeting the Hippo pathway has been researched in a variety of tumors and has been shown to have remarkable results. The combination of targeted therapy for the Hippo pathway and chemotherapy or other targeted

Table 3 Designed clinical trials of agents targeting the Hippo pathway

\begin{tabular}{llllll}
\hline Agents & Mode of action & Study phase & Outcome & Study Title & NCT number \\
\hline Zoledronate, Atorvastatin & Inhibition of YAP/TAZ & Phase 2 & No results available & $\begin{array}{c}\text { Neoadjuvant Zoledronate and Atorv- NCT03358017 } \\
\text { astatin in TNBC }\end{array}$ \\
Atorvastatin & Inhibits TAZ & Phase 2 & No results available & $\begin{array}{c}\text { Targeting the Hippo transducer TAZ } \\
\text { in breast cancer with Statins }\end{array}$ & NCT 02416427 \\
Zoledronate & Inhibits YAP/TAZ & Phase 2 & No results available & Pre-operative zoledronate in TNBC NCT 02347163 \\
\hline
\end{tabular}

Table 4 Clinical trials of endocrine therapy combined with agents targeting Hippo pathway for reference

\begin{tabular}{|c|c|c|c|c|c|}
\hline \multicolumn{2}{|l|}{ Agents } & \multirow[t]{2}{*}{ Study phase } & \multirow[t]{2}{*}{ Outcome } & \multirow[t]{2}{*}{ NCT number } & \multirow[t]{2}{*}{ Possible mechanisms } \\
\hline Hippo pathway & Endocrine therapy & & & & \\
\hline Atorvastatin & Letrozole, Fulvestrant & Phase 2 & No results available & NCT02958852 & \multirow{5}{*}{$\begin{array}{l}\text { Stains inhibits YAP/TAZ nuclear } \\
\text { localization, and suppressed the } \\
\text { self-renewal capability of cancer } \\
\text { stem cells via opposing nuclear } \\
\text { TAZ activity [140] } \\
\text { Metformin inhibits YAP nuclear } \\
\text { localization [141] }\end{array}$} \\
\hline Metformin, Simvastatin & Fulvestrant & Phase 2 & No results available & NCT03192293 & \\
\hline Metformin & Toremifene & Phase 2 & No results available & NCT02506790 & \\
\hline Metformin & Fulvestrant & Phase 2 & No results available & NCT04300790 & \\
\hline Metformin & Everolimus, Exemestane & Phase 2 & $\begin{array}{l}\text { The clinical benefit rate } \\
\text { was } 54.5 \%\end{array}$ & NCT01627067 & \\
\hline
\end{tabular}


Table 5 MiRNAs that regulate the Hippo pathway in breast cancer

\begin{tabular}{|c|c|c|c|c|c|}
\hline MiRNAs & & $\begin{array}{l}\text { Tumor suppressor } \\
(-) / \text { tumor promotor } \\
(+)\end{array}$ & Cell lines & Targets & Mechanisms of regulation \\
\hline MiR-326 [142] & & - & MCF-7, MDA-MB-468 & TAZ & $\begin{array}{l}\text { Circular RNA } 0000511 \text { can eliminate the } \\
\text { anti-tumor effect of miR-326 by upregulat- } \\
\text { ing TAZ }\end{array}$ \\
\hline MiR-146b [143] & & - & MCF-7 & $\mathrm{p}-\mathrm{YAP}$ & $\begin{array}{l}\text { The process of MUC19 reducing YAP phos- } \\
\text { phorylation is inhibited by miR-146b }\end{array}$ \\
\hline MiR-199a-3p [133] & & - & MDA-MB-231 & LATS1, YAP1 & $\begin{array}{l}\text { miR-199a-3p suppresses YAP1 and upregu- } \\
\text { lates LATS1 }\end{array}$ \\
\hline MiR-574-5p [135] & & - & MDA-MB-231, T47D & TAZ & miR-574-5p targets Sox2 to suppress TAZ \\
\hline MiR-1297 [144] & - & & MDA-MB-231, MDA-MB-468 & TAZ & miR-1297 inhibits TAZ \\
\hline MiR-125a-5p $[145,146]$ & - & & $\begin{array}{l}\text { MDA-MB-468, BT549, tamox- } \\
\text { ifen resistant MCF7 }\end{array}$ & TAZ & $\begin{array}{l}\text { miR-125a-5p directly inhibits TAZ expression. } \\
\text { Downregulation of CYTOR decreases pro- } \\
\text { tein and mRNA levels of TAZ in tamoxifen } \\
\text { resistant MCF7 cells, which is rescued by } \\
\text { miR-125a-5p suppression }\end{array}$ \\
\hline MiR-515-5p [147] & + & & MDA-MB-231, MDA-MB-453 & YAP, TAZ, p-TAZ & $\begin{array}{l}\text { Knockdown LINC00673 reduces the level of } \\
\text { YAP/TAZ and increases p-YAP through miR- } \\
515-5 p \text { inactivation }\end{array}$ \\
\hline MiR-591 [148] & - & & MCF-7, SKBR3 & YAP, LATS & miR-591 inhibits YAP and upregulates LATS \\
\hline MiR-520b [94] & + & & MCF-7, MDA-MB-231 & LATS2, p-YAP, YAP & $\begin{array}{l}\text { miR-520b promotes migration activity and } \\
\text { stemness of breast cancer, which can be } \\
\text { abolished by overexpression of LATS2. miR- } \\
520 \text { b upregulates nuclear YAP and inhibits } \\
\text { LATS2 as well as P-YAP }\end{array}$ \\
\hline MiR-372 [149] & + & & MCF-7, MDA-MB-231 & LATS2 & miR-372 inhibits LATS2 \\
\hline MiR-18a [150] & - & & Trastuzumab-resistant SKBR-3 & YAP1 & miR-18a directly inhibits YAP1 \\
\hline MiR-424 [151] & - & & MDA-MB-231, HCC-1937 & YAP & miR-424 inhibits YAP \\
\hline MiR-205 [134] & - & & SUM159 & TAZ & $\begin{array}{l}\text { miR-205 inhibits TAZ, which is involved in } \\
\text { the mammospheres formation and BCSC } \\
\text { renewal }\end{array}$ \\
\hline MiR-135b [152] & + & & MDA-MB-231, MCF-7, $293 \mathrm{~T}$ & LATS2, & miR-135b inhibits LATS2 \\
\hline MiR-506 [153] & - & & MDA-MB-231 & YAP & miR-506 inhibits YAP \\
\hline MiR-31 [154] & + & & MDA-MB-231 & LATS2 & miR-31 inhibits LATS2 \\
\hline MiR-93 [155] & + & & MT-1 & LATS2 & miR-93 inhibits LATS2 \\
\hline
\end{tabular}

therapies has also achieved initial results in breast cancers. Although its dysregulation can promote the occurrence and progression of tumors, reasonable regulation of this pathway can effectively inhibit tumors and combat endocrine resistance. However, the Hippo pathway is powerful, diverse, and complex. Breast cancers differ from other tumors, in that the former is derived from more of the non-canonical roles of the Hippo pathway via hormone receptors. More studies are needed to verify the feasibility and risk of regulation of the Hippo pathway in endocrine-resistant breast cancer. Moreover, our laboratory has shown that aromatase inhibitors such as
Formestane can rely on ER-independent but androgen receptor-dependent roles to suppress ER + breast cancer, suggesting that aromatase inhibitors may be highly recommended as promising agents combined with targeting the Hippo pathway to significantly overcome endocrine resistance stimulated by estrogen-deprivation therapy in postmenopausal women [157]. Targeting the Hippo pathway will create promising new tools in the fight against endocrine-resistant breast cancer. 


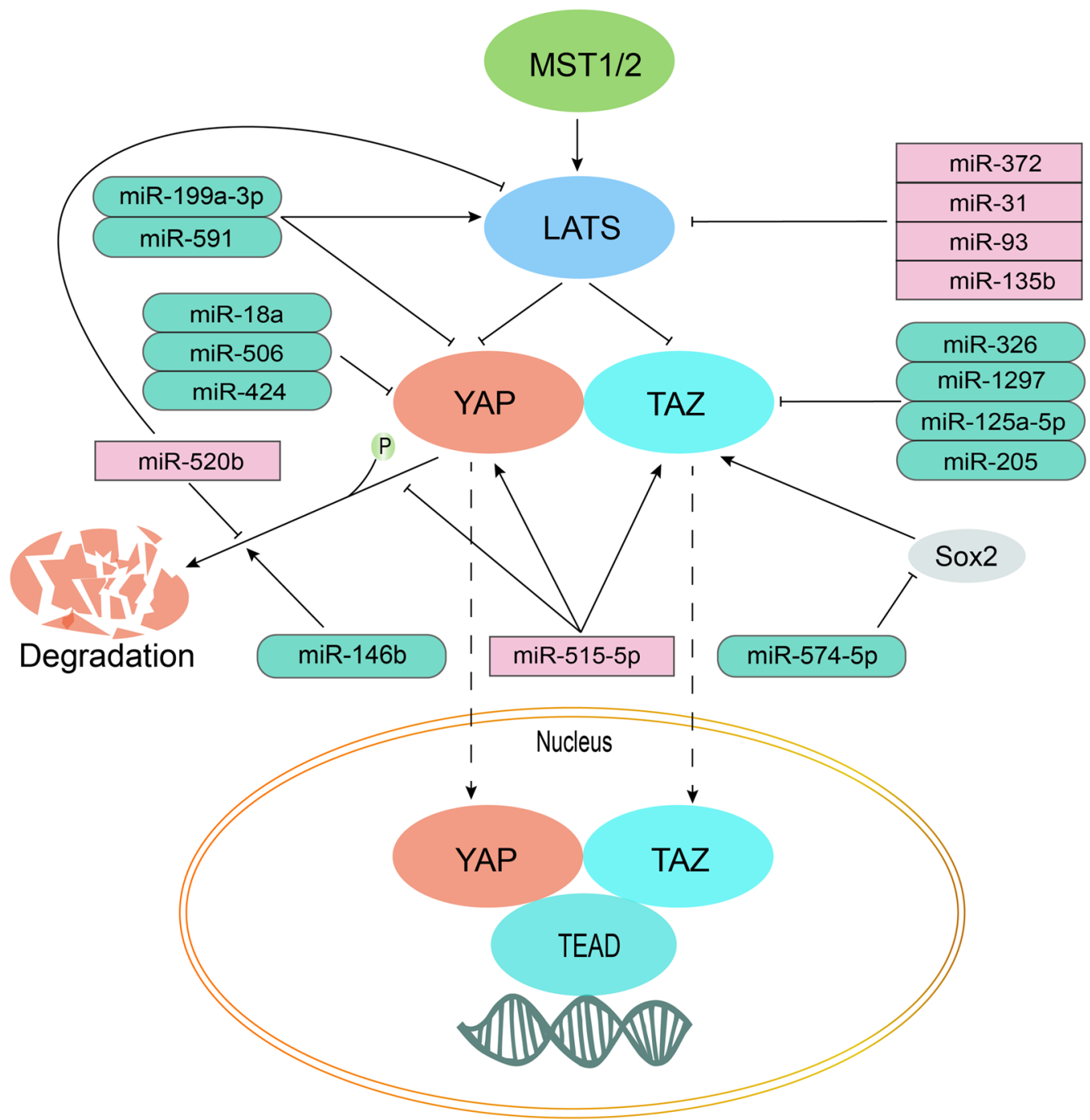

Fig. 7 Illustration of miRNAs in regulation of the Hippo pathway. MiRNAs dysregulate the Hippo pathway by inhibiting LATS and phosphorylation of YAP, or directly upregulating YAP and TAZ. MiR-520b, miR-372, miR-31, miR-93, miR-135b and miR-515-5p are tumor promotors with the dysregulation of the Hippo pathway. On the contrary, miR-199a-3p, miR-591, miR-18a, miR-506, miR-424, miR-146b, miR-574-5p, miR-205, miR-125a-5p, miR-1297 and miR-326 are tumor suppressors with the activation of the Hippo pathways

\section{Abbreviations}

TNBC: Triple negative breast cancer; FOXM1: Fork head box protein M1; BCSCs: Breast cancer stem cells; USP9X: Ubiquitin-specific protease 9X; ER +: Estrogen receptor-positive; CDKs: Cyclin-dependent kinases; mTOR: Mammalian target of rapamycin; WBP2: WW domain-binding protein 2; E2: Estradiol; PI3K: Phosphoinositide 3-kinase; ER: Estrogen receptor; GFR: Growth factor receptor; PFS: Progression-free survival; GPER: G protein-coupled estrogen receptor; ER - : Estrogen receptor negative; Hh: Hedgehog; TGF- $\beta$ : Transforming growth factor $\beta$; IMP3: Insulin-like growth factor-2 mRNA-binding protein 3; EGFR: Epidermal growth factor receptor; ERE: Estrogen response element; MAPK: Mitogen-activated protein kinase; CRABP2: Cellular retinoic acid binding protein 2; HER2: Human epidermal growth factor receptor 2; FGFR: Fibroblast growth factor receptor 1; NCoR1: Nuclear transcriptional corepressor N-CoR1; BCAR4: Breast cancer anti-estrogen resistance 4; IGF-1 R: Insulin-like growth factor 1 receptor; YAP: Yes-associated protein; Linc-OIP5: Linc-Opa interacting protein 5; TAZ: Transcriptional coactivator with PDZ-binding motif; MUC1-C: The mucin 1 C-terminal subunit; MST: Mammalian sterile20-like; LATS: Large tumor suppressor; TEAD: TEA domain family members; ZNF367: Zinc finger protein 367; EPI: Epinephrine; NE: Norepinephrine; ceRNA: Competing endogenous RNA; ERK1: Extracellular signal-related kinases 1.

\section{Acknowledgements}

We thank all the members of Sichuan Provincial Center for Gynaecology and Breast Disease for the technical assistance and research support.

\section{Authors' contributions}

ATT was in charge of conception, design, investigation, data analyses, funding acquisition, editing, review and formal analysis of the findings being published. JC wrote original draft and drew figures. JC gave assistance to investigation, data analyses, translation. RLW was responsible for supervising the process. QQL, ZHR, YLW and LZ gave assistance to translation and language. All authors read and approved the final manuscript.

\section{Funding}

This research was funded by the Fund for High-level Talents in Luzhou City (No. 02-00040055). 
Availability of data and materials

Not applicable.

\section{Declarations}

Ethics approval and consent to participate

Not applicable.

\section{Consent for publication}

Not applicable.

\section{Competing interests}

The authors declare that they have no competing interests.

\section{Author details}

${ }^{1}$ Department of Gynaecology and Obstetrics, The Affiliated Hospital of Southwest Medical University, No. 25 Taiping Street, Jiangyang District, Luzhou 646000, People's Republic of China. ${ }^{2}$ Sichuan Provincial Center for Gynaecology and Breast Diseases, The Affiliated Hospital of Southwest Medical University, Luzhou 646000, China. ${ }^{3}$ North Sichuan Medical College, Nanchong 637000, China. ${ }^{4}$ Department of Gynaecology, The Second People's Hospital of Yibin, Yibin 644000, China.

Received: 19 March 2021 Accepted: 27 May 2021

Published online: 10 June 2021

\section{References}

1. Bray F, Ferlay J, Soerjomataram I, Siegel RL, Torre LA, Jemal A. Global cancer statistics 2018: GLOBOCAN estimates of incidence and mortality worldwide for 36 cancers in 185 countries. CA Cancer J Clin. 2018;68(6):394-424. https://doi.org/10.3322/caac.21492.

2. Effects of chemotherapy and hormonal therapy for early breast cancer on recurrence and 15-year survival: an overview of the randomised trials. The Lancet. 2005;365(9472):1687-717. https://doi.org/10.1016/ s0140-6736(05)66544-0.

3. Pennery $E$. The role of endocrine therapies in reducing risk of recurrence in postmenopausal women with hormone receptor-positive breast cancer. Eur J Oncol Nurs. 2008;12(3):233-43. https://doi.org/10. 1016/j.ejon.2008.01.007

4. Giuliano M, Schettini F, Rognoni C, Milani M, Jerusalem G, Bachelot T, et al. Endocrine treatment versus chemotherapy in postmenopausal women with hormone receptor-positive, HER2-negative, metastatic breast cancer: a systematic review and network meta-analysis. Lancet Oncol. 2019;20(10):1360-9. https://doi.org/10.1016/S1470-2045(19) 30420-6.

5. Li Z, Razavi P, Li Q, Toy W, Liu B, Ping C, et al. Loss of the FAT1 tumor suppressor promotes resistance to CDK4/6 inhibitors via the Hippo pathway. Cancer Cell. 2018;34(6):893-905e8. https://doi.org/10.1016/j. ccell.2018.11.006.

6. Pancholi S, Ribas R, Simigdala N, Schuster E, Nikitorowicz-Buniak J, Ressa $A$, et al. Tumour kinome re-wiring governs resistance to palbociclib in oestrogen receptor positive breast cancers, highlighting new therapeutic modalities. Oncogene. 2020;39(25):4781-97. https://doi.org/10. 1038/s41388-020-1284-6.

7. Baselga J, Campone M, Piccart M, Burris HA 3rd, Rugo HS, Sahmoud T, et al. Everolimus in postmenopausal hormone-receptor-positive advanced breast cancer. N Engl J Med. 2012;366(6):520-9. https://doi. org/10.1056/NEJMoa1109653.

8. Park YH, Kim TY, Kim GM, Kang SY, Park IH, Kim JH, et al. Palbociclib plus exemestane with gonadotropin-releasing hormone agonist versus capecitabine in premenopausal women with hormone receptorpositive, HER2-negative metastatic breast cancer (KCSG-BR15-10): a multicentre, open-label, randomised, phase 2 trial. Lancet Oncol. 2019;20(12):1750-9. https://doi.org/10.1016/S1470-2045(19)30565-0.

9. Hortobagyi GN, Stemmer SM, Burris HA, Yap YS, Sonke GS, PaluchShimon S, et al. Ribociclib as first-line therapy for HR-positive, advanced breast cancer. N Engl J Med. 2016;375(18):1738-48. https://doi.org/10. 1056/NEJMoa1609709.
10. Johnston SRD, Harbeck N, Hegg R, Toi M, Martin M, Shao ZM, et al. Abemaciclib combined with endocrine therapy for the adjuvant treatment of $\mathrm{HR}+, \mathrm{HER} 2-$, node-positive, high-risk, early breast cancer (monarchE). J Clin Oncol. 2020;38(34):3987-98. https://doi.org/10.1200/ jco.20.02514.

11. Andre F, Ciruelos E, Rubovszky G, Campone M, Loibl S, Rugo HS, et al. Alpelisib for PIK3CA-mutated, hormone receptor-positive advanced breast cancer. N Engl J Med. 2019;380(20):1929-40. https://doi.org/10. 1056/NEJMoa1813904.

12. Piva M, Domenici G, Iriondo O, Rabano M, Simoes BM, Comaills V, et al. Sox2 promotes tamoxifen resistance in breast cancer cells. EMBO Mol Med. 2014;6(1):66-79. https://doi.org/10.1002/emmm.201303411.

13. Dubrovska A, Hartung A, Bouchez LC, Walker JR, Reddy VA, Cho CY, et al. CXCR4 activation maintains a stem cell population in tamoxifenresistant breast cancer cells through AhR signalling. Br J Cancer. 2012;107(1):43-52. https://doi.org/10.1038/bjc.2012.105.

14. Liu H, Zhang HW, Sun XF, Guo XH, He YN, Cui SD, et al. Tamoxifenresistant breast cancer cells possess cancer stem-like cell properties. Chin Med J (Engl). 2013;126(16):3030-4. https://doi.org/10.3760/cma.j. issn.0366-6999.20130227.

15. El-Sheemy M, Hussain I, Rea C, Arif K. The role of Nanog expression in tamoxifen-resistant breast cancer cells. OncoTargets Ther. 2015;8:132734. https://doi.org/10.2147/ott.S67835.

16. Domenici G, Aurrekoetxea-Rodriguez I, Simoes BM, Rabano M, Lee SY, Millan JS, et al. A Sox2-Sox9 signalling axis maintains human breast luminal progenitor and breast cancer stem cells. Oncogene. 2019;38(17):3151-69. https://doi.org/10.1038/s41388-018-0656-7.

17. Creighton CJ, Li X, Landis M, Dixon JM, Neumeister VM, Sjolund A, et al. Residual breast cancers after conventional therapy display mesenchymal as well as tumor-initiating features. Proc Nat Acad Sci. 2009:106(33):13820-5. https://doi.org/10.1073/pnas.0905718106.

18. Simoes BM, O'Brien CS, Eyre R, Silva A, Yu L, Sarmiento-Castro A, et al. Anti-estrogen resistance in human breast tumors is driven by JAG1-NOTCH4-dependent cancer stem cell activity. Cell Rep. 2015;12(12):1968-77. https://doi.org/10.1016/j.celrep.2015.08.050.

19. Sansone P, Ceccarelli C, Berishaj M, Chang Q, Rajasekhar VK, Perna F, et al. Self-renewal of CD133(hi) cells by IL6/Notch3 signalling regulates endocrine resistance in metastatic breast cancer. Nat Commun 2016;7:10442. https://doi.org/10.1038/ncomms10442.

20. Gelsomino L, Panza S, Giordano C, Barone I, Gu G, Spina E, et al. Mutations in the estrogen receptor alpha hormone binding domain promote stem cell phenotype through notch activation in breast cancer cell lines. Cancer Lett. 2018;428:12-20. https://doi.org/10.1016/j.canlet. 2018.04.023.

21. Deng H, Zhang XT, Wang ML, Zheng HY, Liu LJ, Wang ZY. ER-alpha36mediated rapid estrogen signaling positively regulates ER-positive breast cancer stem/progenitor cells. PLoS ONE. 2014;9(2):e88034. https://doi.org/10.1371/journal.pone.0088034.

22. Ma R, Karthik GM, Lovrot J, Haglund F, Rosin G, Katchy A, et al. Estrogen receptor beta as a therapeutic target in breast cancer stem cells. J Natl Cancer Inst. 2017;109(3):1-14. https://doi.org/10.1093/jnci/djw236.

23. Chan YT, Lai AC, Lin RJ, Wang YH, Wang YT, Chang WW, et al. GPERinduced signaling is essential for the survival of breast cancer stem cells. Int J Cancer. 2020;146(6):1674-85. https://doi.org/10.1002/ijc. 32588.

24. Eden JA. Human breast cancer stem cells and sex hormones. Menopause. 2010;17(4):801-10. https://doi.org/10.1097/gme.0b013e3181 d3cdd7.

25. Shipitsin M, Campbell LL, Argani P, Weremowicz S, Bloushtain-Qimron $\mathrm{N}$, Yao J, et al. Molecular definition of breast tumor heterogeneity. Cancer Cell. 2007;11(3):259-73. https://doi.org/10.1016/j.ccr.2007.01.013.

26. Liu S, Ginestier C, Charafe-Jauffret E, Foco H, Kleer CG, Merajver SD, et al. BRCA1 regulates human mammary stem/progenitor cell fate. Proc Natl Acad Sci USA. 2008:105(5):1680-5. https://doi.org/10.1073/pnas.07116 13105.

27. Buckley NE, Nic An tSaoir CB, Blayney JK, Oram LC, Crawford NT, D'Costa ZC, et al. BRCA1 is a key regulator of breast differentiation through activation of Notch signalling with implications for anti-endocrine treatment of breast cancers. Nucleic Acids Res. 2013;41(18):8601-14. https://doi.org/10.1093/nar/gkt626. 
28. Ojo D, Wei F, Liu Y, Wang E, Zhang H, Lin X, et al. Factors promoting tamoxifen resistance in breast cancer via stimulating breast cancer stem cell expansion. Curr Med Chem. 2015;22(19):2360-74. https://doi. org/10.2174/0929867322666150416095744.

29. Chen C, Baumann WT, Clarke R, Tyson JJ. Modeling the estrogen receptor to growth factor receptor signaling switch in human breast cancer cells. FEBS Lett. 2013;587(20):3327-34. https://doi.org/10.1016/j.febslet. 2013.08.022.

30. Massarweh S, Schiff R. Resistance to endocrine therapy in breast cancer: exploiting estrogen receptor/growth factor signaling crosstalk. Endocr Relat Cancer. 2006;13(Suppl 1):S15-24. https://doi.org/10.1677/erc.1. 01273.

31. Martinez-Revollar G, Garay E, Martin-Tapia D, Nava P, Huerta M, Lopez-

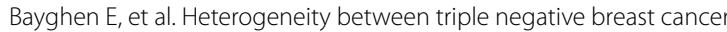
cells due to differential activation of Wnt and PI3K /AKT pathways. Exp Cell Res. 2015;339(1):67-80. https://doi.org/10.1016/j.yexcr.2015.10.006.

32. Schlange T, Matsuda Y, Lienhard S, Huber A, Hynes NE. Autocrine WNT signaling contributes to breast cancer cell proliferation via the canonical WNT pathway and EGFR transactivation. Breast Cancer Res. 2007:9(5):R63. https://doi.org/10.1186/bcr1769.

33. O'Brien CS, Howell SJ, Farnie G, Clarke RB. Resistance to endocrine therapy: are breast cancer stem cells the culprits? J Mam Gland Biol Neoplasia. 2009;14(1):45-54. https://doi.org/10.1007/s10911-009-9115-y.

34. Manupati K, Dhoke NR, Debnath T, Yeeravalli R, Guguloth K, Saeidpour $S$, et al. Inhibiting epidermal growth factor receptor signalling potentiates mesenchymal-epithelial transition of breast cancer stem cells and their responsiveness to anticancer drugs. Febs J. 2017;284(12):1830-54. https://doi.org/10.1111/febs.14084.

35. Roop RP, Ma CX. Endocrine resistance in breast cancer: molecular pathways and rational development of targeted therapies. Future Oncol. 2012:8(3):273-92. https://doi.org/10.2217/fon.12.8.

36. Johnston S, Basik M, Hegg R, Lausoontornsiri W, Grzeda L, Clemons $M$, et al. Inhibition of EGFR, HER2, and HER3 signaling with AZD8931 in combination with anastrozole as an anticancer approach: phase II randomized study in women with endocrine-therapy-naive advanced breast cancer. Breast Cancer Res Treat. 2016;160(1):91-9. https://doi. org/10.1007/s10549-016-3979-5.

37. Burstein HJ, Cirrincione CT, Barry WT, Chew HK, Tolaney SM, Lake DE, et al. Endocrine therapy with or without inhibition of epidermal growth factor receptor and human epidermal growth factor receptor 2: a randomized, double-blind, placebo-controlled phase III trial of fulvestrant with or without lapatinib for postmenopausal women with hormone receptor-positive advanced breast cancer-CALGB 40302 (Alliance). J Clin Oncol. 2014;32(35):3959-66. https://doi.org/10.1200/JCO.2014.56. 7941 .

38. Smith IE, Walsh G, Skene A, Llombart A, Mayordomo JI, Detre S, et al. A phase II placebo-controlled trial of neoadjuvant anastrozole alone or with gefitinib in early breast cancer. J Clin Oncol. 2007;25(25):3816-22. https://doi.org/10.1200/JCO.2006.09.6578.

39. Green MD, Francis PA, Gebski V, Harvey V, Karapetis C, Chan A, et al. Gefitinib treatment in hormone-resistant and hormone receptor-negative advanced breast cancer. Ann Oncol. 2009;20(11):1813-7. https://doi. org/10.1093/annonc/mdp202

40. Tryfonidis K, Basaran G, Bogaerts J, Debled M, Dirix L, Thery JC, et al. A European Organisation for Research and Treatment of Cancer randomized, double-blind, placebo-controlled, multicentre phase II trial of anastrozole in combination with gefitinib or placebo in hormone receptor-positive advanced breast cancer (NCT00066378). Eur J Cancer. 2016;53:144-54. https://doi.org/10.1016/j.ejca.2015.10.012.

41. Fukui F, Hayashi SI, Yamaguchi Y. Heregulin controls ERalpha and HER2 signaling in mammospheres of ERalpha-positive breast cancer cells and interferes with the efficacy of molecular targeted therapy. J Steroid Biochem Mol Biol. 2020;201:105698. https://doi.org/10.1016/j.jsbmb. 2020.105698.

42. Hardt O, Wild S, Oerlecke I, Hofmann K, Luo S, Wiencek Y, et al. Highly sensitive profiling of CD44+/CD24- breast cancer stem cells by combining global mRNA amplification and next generation sequencing: evidence for a hyperactive PI3K pathway. Cancer Lett. 2012;325(2):16574. https://doi.org/10.1016/j.canlet.2012.06.010

43. Karthik GM, Ma R, Lövrot J, Kis LL, Lindh C, Blomquist L, et al. mTOR inhibitors counteract tamoxifen-induced activation of breast cancer stem cells. Cancer Lett. 2015;367(1):76-87. https://doi.org/10.1016/j. canlet.2015.07.017.

44. Lu PW, Li L, Wang F, Gu YT. Inhibitory role of large intergenic noncoding RNA-ROR on tamoxifen resistance in the endocrine therapy of breast cancer by regulating the PI3K/Akt/mTOR signaling pathway. J Cell Physiol. 2019;234(2):1904-12. https://doi.org/10.1002/jcp.27066.

45. Beelen K, Hoefnagel LD, Opdam M, Wesseling J, Sanders J, Vincent AD, et al. PI3K/AKT/mTOR pathway activation in primary and corresponding metastatic breast tumors after adjuvant endocrine therapy. Int J Cancer. 2014;135(5):1257-63. https://doi.org/10.1002/ijc.28769.

46. Yin L, Zhang XT, Bian XW, Guo YM, Wang ZY. Disruption of the ER-a36EGFR/HER2 positive regulatory loops restores tamoxifen sensitivity in tamoxifen resistance breast cancer cells. PLoS ONE. 2014;9(9):e107369. https://doi.org/10.1371/journal.pone.0107369.

47. Deng H, Zhang XT, Wang ML, Zheng HY, Liu LJ, Wang ZY. ER-a36mediated rapid estrogen signaling positively regulates ER-positive breast cancer stem/progenitor cells. PLoS ONE. 2014;9(2):e88034. https://doi.org/10.1371/journal.pone.0088034.

48. Kang L, Guo Y, Zhang X, Meng J, Wang ZY. A positive cross-regulation of HER2 and ER-a36 controls ALDH1 positive breast cancer cells. J Steroid Biochem Mol Biol. 2011;127(3-5):262-8. https://doi.org/10.1016/j. jsbmb.2011.08.011.

49. Zhao L, Qiu T, Jiang D, Xu H, Zou L, Yang Q, et al. SGCE promotes breast cancer stem cells by stabilizing EGFR. Adv Sci (Weinh). 2020;7(14):1903700. https://doi.org/10.1002/advs.201903700.

50. Arpino G, Green SJ, Allred DC, Lew D, Martino S, Osborne CK, et al. HER-2 amplification, HER-1 expression, and tamoxifen response in estrogen receptor-positive metastatic breast cancer: a southwest oncology group study. Clin Cancer Res. 2004;10(17):5670-6. https://doi. org/10.1158/1078-0432.Ccr-04-0110.

51. Jeong Y, Bae SY, You D, Jung SP, Choi HJ, Kim I, et al. EGFR is a therapeutic target in hormone receptor-positive breast cancer. Cell Physiol Biochem. 2019;53(5):805-19. https://doi.org/10.33594/000000174.

52. Berardi DE, Raffo D, Todaro LB, Simian M. Laminin modulates the stem cell population in LM05-E murine breast cancer cells through the activation of the MAPK/ERK pathway. Cancer Res Treat. 2017;49(4):869-79. https://doi.org/10.4143/crt.2016.378.

53. Xu C, Sun X, Qin S, Wang H, Zheng Z, Xu S, et al. Let-7a regulates mammosphere formation capacity through Ras/NF-kB and Ras/MAPK/ERK pathway in breast cancer stem cells. Cell Cycle. 2015;14(11):1686-97. https://doi.org/10.1080/15384101.2015.1030547.

54. Xu M, Ren Z, Wang X, Comer A, Frank JA, Ke ZJ, et al. ErbB2 and p38Y MAPK mediate alcohol-induced increase in breast cancer stem cells and metastasis. Mol Cancer. 2016;15(1):52. https://doi.org/10.1186/ s12943-016-0532-4.

55. Rhodes LV, Short SP, Neel NF, Salvo VA, Zhu Y, Elliott S, et al. Cytokine receptor CXCR4 mediates estrogen-independent tumorigenesis, metastasis, and resistance to endocrine therapy in human breast cancer. Cancer Res. 2011;71(2):603-13. https://doi.org/10.1158/0008-5472. CAN-10-3185.

56. Jia Y, Zhou J, Luo X, Chen M, Chen Y, Wang J, et al. KLF4 overcomes tamoxifen resistance by suppressing MAPK signaling pathway and predicts good prognosis in breast cancer. Cell Signal. 2018;42:165-75. https://doi.org/10.1016/j.cellsig.2017.09.025.

57. Sakunrangsit N, Ketchart W. Plumbagin inhibits cancer stem-like cells, angiogenesis and suppresses cell proliferation and invasion by targeting Wnt/beta-catenin pathway in endocrine resistant breast cancer. Pharmacol Res. 2019;150:104517. https://doi.org/10.1016/j.phrs.2019. 104517.

58. Fu Y, Wang Z, Luo C, Wang Y, Wang Y, Zhong X, et al. Downregulation of CXXC finger protein 4 leads to a tamoxifen-resistant phenotype in breast cancer cells through activation of the Wnt/beta-catenin pathway. Transl Oncol. 2020;13(2):423-40. https://doi.org/10.1016/j.tranon. 2019.12.005

59. Zheng W, Duan B, Zhang Q, Ouyang L, Peng W, Qian F, et al. Vitamin $D$-induced vitamin D receptor expression induces tamoxifen sensitivity in MCF-7 stem cells via suppression of Wnt/beta-catenin signaling. Biosci Rep. 2018;38(6). 10.1042/BSR20180595.

60. Zhou M, Hou Y, Yang G, Zhang H, Tu G, Du YE, et al. LncRNA-Hh strengthen cancer stem cells generation in twist-positive breast 
cancer via activation of hedgehog signaling pathway. Stem Cells. 2016;34(1):55-66. https://doi.org/10.1002/stem.2219.

61. Ramaswamy B, Lu Y, Teng Ky, Nuovo G, Li X, Shapiro CL, et al. Hedgehog signaling is a novel therapeutic target in tamoxifen-resistant breast cancer aberrantly activated by PI3K/AKT pathway. Cancer Res. 2012;72(19):5048-59. https://doi.org/10.1158/0008-5472.Can-12-1248.

62. Bhateja P, Cherian M, Majumder S, Ramaswamy B. The Hedgehog signaling pathway: a viable target in breast cancer? Cancers (Basel). 2019;11(8):1126. https://doi.org/10.3390/cancers11081126.

63. Sansone P, Berishaj M, Rajasekhar VK, Ceccarelli C, Chang Q, Strillacci A, et al. Evolution of cancer stem-like cells in endocrine-resistant metastatic breast cancers is mediated by stromal microvesicles. Cancer Res. 2017;77(8):1927-41. https://doi.org/10.1158/0008-5472.CAN-16-2129.

64. Lombardo Y, Faronato M, Filipovic A, Vircillo V, Magnani L, Coombes RC. Nicastrin and Notch4 drive endocrine therapy resistance and epithelial to mesenchymal transition in MCF7 breast cancer cells. Breast Cancer Res. 2014;16(3):R62. https://doi.org/10.1186/bcr3675.

65. Wang Y, Yu Y, Tsuyada A, Ren X, Wu X, Stubblefield K, et al. Transforming growth factor- $\beta$ regulates the sphere-initiating stem cell-like feature in breast cancer through miRNA-181 and ATM. Oncogene. 2011;30(12):1470-80. https://doi.org/10.1038/onc.2010.531.

66. Nie Z, Wang C, Zhou Z, Chen C, Liu R, Wang D. Transforming growth factor-beta increases breast cancer stem cell population partially through upregulating PMEPA1 expression. Acta Biochim Biophys Sin (Shanghai). 2016;48(2):194-201. https://doi.org/10.1093/abbs/gmv130.

67. Zavadova E, Vocka M, Spacek J, Konopasek B, Fucikova T, Petruzelka L. Cellular and humoral immunodeficiency in breast cancer patients resistant to hormone therapy. Neoplasma. 2014;61 (01):90-8. https://doi. org/10.4149/neo_2014_013.

68. Sieuwerts AM, Inda MA, Smid M, van Ooijen $H$, van de Stolpe A, Martens JWM, et al. ER and PI3K pathway activity in primary ER positive breast cancer is associated with progression-free survival of metastatic patients under first-line tamoxifen. Cancers (Basel). 2020;12(4):802. https://doi.org/10.3390/cancers12040802.

69. Knabbe C, Lippman ME, Wakefield LM, Flanders KC, Kasid A, Derynck $\mathrm{R}$, et al. Evidence that transforming growth factor-beta is a hormonally regulated negative growth factor in human breast cancer cells. Cell. 1987;48(3):417-28. https://doi.org/10.1016/0092-8674(87)90193-0.

70. Camargo FD, Gokhale S, Johnnidis JB, Fu D, Bell GW, Jaenisch R, et al. YAP1 increases organ size and expands undifferentiated progenitor cells. Curr Biol. 2007;17(23):2054-60. https://doi.org/10.1016/j.cub.2007. 10.039 .

71. Thompson BJ. YAP/TAZ: drivers of tumor growth, metastasis, and resistance to therapy. BioEssays. 2020;42(5):e1900162. https://doi.org/10. 1002/bies.201900162

72. Zanconato F, Cordenonsi M, Piccolo S. YAP/TAZ at the roots of cancer. Cancer Cell. 2016;29(6):783-803. https://doi.org/10.1016/j.ccell.2016.05. 005.

73. Song H, Mak KK, Topol L, Yun K, Hu J, Garrett L, et al. Mammalian Mst1 and Mst2 kinases play essential roles in organ size control and tumor suppression. Proc Natl Acad Sci USA. 2010;107(4):1431-6. https://doi. org/10.1073/pnas.0911409107.

74. Hao Y, Chun A, Cheung K, Rashidi B, Yang X. Tumor suppressor LATS1 is a negative regulator of oncogene YAP. J Biol Chem. 2008;283(9):5496509. https://doi.org/10.1074/jbc.M709037200.

75. Yang X, Li DM, Chen W, XU T. Human homologue of Drosophila lats, LATS1, negatively regulate growth by inducing $\mathrm{G}(2) / \mathrm{M}$ arrest or apoptosis. Oncogene. 2001;20(45):6516-23. https://doi.org/10.1038/sj.onc. 1204817.

76. Ke H, Pei J, Ni Z, Xia H, Qi H, Woods T, et al. Putative tumor suppressor Lats2 induces apoptosis through downregulation of $\mathrm{BCl}-2$ and $\mathrm{BCl}-\mathrm{x}(\mathrm{L})$. Exp Cell Res. 2004;298(2):329-38. https://doi.org/10.1016/j.yexcr.2004. 04.031.

77. Stewart RA, Li DM, Huang $H, X U T$. A genetic screen for modifiers of the lats tumor suppressor gene identifies C-terminal Src kinase as a regulator of cell proliferation in Drosophila. Oncogene. 2003;22(41):6436-44. https://doi.org/10.1038/sj.onc.1206820.

78. Bao Y, Nakagawa K, Yang Z, Ikeda M, Withanage K, Ishigami-Yuasa M, et al. A cell-based assay to screen stimulators of the Hippo pathway reveals the inhibitory effect of dobutamine on the YAP-dependent gene transcription. J Biochem. 2011;150(2):199-208. https://doi.org/10. 1093/jb/mvr063.

79. Zhao W, Wang M, Cai M, Zhang C, Qiu Y, Wang X, et al. Transcriptional co-activators YAP/TAZ: potential therapeutic targets for metastatic breast cancer. Biomed Pharmacother. 2021;133:110956. https://doi.org/ 10.1016/j.biopha.2020.110956.

80. Kim E, Kang JG, Kang MJ, Park JH, Kim YJ, Kweon TH, et al. O-GlcNAcylation on LATS2 disrupts the Hippo pathway by inhibiting its activity. Proc Natl Acad Sci USA. 2020;117(25):14259-69. https://doi.org/10.1073/ pnas.1913469117.

81. Raghunathan VK, Dreier B, Morgan JT, Tuyen BC, Rose BW, Reilly CM, et al. Involvement of YAP, TAZ and HSP90 in contact guidance and intercellular junction formation in corneal epithelial cells. PLOS ONE. 2014;9(10):e109811. https://doi.org/10.1371/journal.pone.0109811.

82. Gill MK, Christova T, Zhang YY, Gregorieff A, Zhang L, Narimatsu $M$, et al. A feed forward loop enforces YAP/TAZ signaling during tumorigenesis. Nat Commun. 2018;9(1):3510. https://doi.org/10.1038/ s41467-018-05939-2.

83. Zhou D, Zhang Y, Wu H, Barry E, Yin Y, Lawrence E, et al. Mst1 and Mst2 protein kinases restrain intestinal stem cell proliferation and colonic tumorigenesis by inhibition of Yes-associated protein (Yap) overabundance. Proc Natl Acad Sci USA. 2011;108(49):E1312-20. https://doi.org/ 10.1073/pnas.1110428108.

84. Ma Y, Yang Y, Wang F, Wei Q, Qin H. Hippo-YAP signaling pathway: a new paradigm for cancer therapy. Int J Cancer. 2015;137(10):2275-86. https://doi.org/10.1002/ijc.29073.

85. Clara JA, Monge C, Yang Y, Takebe N. Targeting signalling pathways and the immune microenvironment of cancer stem cells - a clinical update. Nat Rev Clin Oncol. 2020;17(4):204-32. https://doi.org/10.1038/ s41571-019-0293-2.

86. Fallahi E, O'Driscoll NA, Matallanas D. The MST/Hippo pathway and cell death: a non-canonical affair. Genes (Basel). 2016;7(6):28. https://doi. org/10.3390/genes 7060028 .

87. Azad T, Janse van Rensburg HJ, Lightbody ED, Neveu B, Champagne A, Ghaffari A, et al. A LATS biosensor screen identifies VEGFR as a regulator of the Hippo pathway in angiogenesis. Nat Commun. 2018;9(1):1061. https://doi.org/10.1038/s41467-018-03278-w.

88. Cordenonsi M, Zanconato F, Azzolin L, Forcato M, Rosato A, Frasson C et al. The Hippo transducer TAZ confers cancer stem cell-related traits on breast cancer cells. Cell. 2011;147(4):759-72. https://doi.org/10. 1016/j.cell.2011.09.048.

89. Duss S, Britschgi A, Bentires-Alj M. Hippo inactivation feeds tumor-initiating cells. Breast Cancer Res. 2012;14(4):318. https://doi.org/10.1186/ bcr3190.

90. Liu J, Li J, Li P, Jiang Y, Chen H, Wang R, et al. DLG5 suppresses breast cancer stem cell-like characteristics to restore tamoxifen sensitivity by inhibiting TAZ expression. J Cell Mol Med. 2019;23(1):512-21. https:// doi.org/10.1111/jcmm.13954.

91. Chang C, Goel HL, Gao H, Pursell B, Shultz LD, Greiner DL, et al. A laminin 511 matrix is regulated by TAZ and functions as the ligand for the alpha6Bbeta1 integrin to sustain breast cancer stem cells. Genes Dev. 2015;29(1):1-6. https://doi.org/10.1101/gad.253682.114.

92. Bartucci M, Dattilo R, Moriconi C, Pagliuca A, Mottolese M, Federici G, et al. TAZ is required for metastatic activity and chemoresistance of breast cancer stem cells. Oncogene. 2015;34(6):681-90. https://doi.org/ 10.1038/onc.2014.5.

93. Li YW, Shen H, Frangou C, Yang N, Guo J, Xu B, et al. Characterization of TAZ domains important for the induction of breast cancer stem cell properties and tumorigenesis. Cell Cycle. 2015;14(1):146-56. https://doi. org/10.4161/15384101.2014.967106.

94. Zhang H, Lang TY, Zou DL, Zhou L, Lou M, Liu JS, et al. miR-520b promotes breast cancer stemness through Hippo/YAP signaling pathway. Onco Targets Ther. 2019;12:11691-700. https://doi.org/10.2147/OTT. S236607.

95. Kim T, Yang SJ, Hwang D, Song J, Kim M, Kyum Kim S, et al. A basal-like breast cancer-specific role for SRF-IL6 in YAP-induced cancer stemness. Nat Commun. 2015;6:10186. https://doi.org/10.1038/ncomms10186.

96. Sorrentino G, Ruggeri N, Zannini A, Ingallina E, Bertolio R, Marotta C, et al. Glucocorticoid receptor signalling activates YAP in breast cancer. Nat Commun. 2017;8:14073. https://doi.org/10.1038/ncomms14073. 
97. Yang CE, Lee WY, Cheng HW, Chung CH, Mi FL, Lin CW. The antipsychotic chlorpromazine suppresses YAP signaling, stemness properties, and drug resistance in breast cancer cells. Chem Biol Interact. 2019;302:28-35. https://doi.org/10.1016/j.cbi.2019.01.033.

98. Britschgi A, Duss S, Kim S, Couto JP, Brinkhaus H, Koren S, et al. The Hippo kinases LATS1 and 2 control human breast cell fate via crosstalk with ERalpha. Nature. 2017;541(7638):541-5. https://doi.org/10.1038/ nature20829.

99. He L, Yuan L, Sun Y, Wang P, Zhang H, Feng $X$, et al. Glucocorticoid receptor signaling activates TEAD4 to promote breast cancer progression. Cancer Res. 2019;79(17):4399-411. https://doi.org/10.1158/00085472.Can-19-0012.

100. Wang Y, Liu J, Ying X, Lin PC, Zhou BP. Twist-mediated epithelial-mesenchymal transition promotes breast tumor cell invasion via inhibition of hippo pathway. Sci Rep. 2016;6:24606. https://doi.org/10.1038/srep2 4606.

101. Zhu C, Li L, Zhang Z, Bi M, Wang H, Su W, et al. A Non-canonical role of YAP/TEAD is required for activation of estrogen-regulated enhancers in breast cancer. Mol Cell. 2019;75(4):791-806e8. https://doi.org/10.1016/j. molcel.2019.06.010.

102. Rosswag S, Thiede G, Sleeman JP, Thaler S. RASSF1A suppresses estrogen-dependent breast cancer cell growth through inhibition of the yes-associated protein 1 (YAP1), inhibition of the forkhead box protein M1 (FOXM1), and activation of forkhead box transcription factor 3A (FOXO3A). Cancers (Basel). 2020;12(9):2689. https://doi.org/10.3390/ cancers12092689.

103. Zhou X, Wang S, Wang Z, Feng X, Liu P, Lv XB, et al. Estrogen regulates Hippo signaling via GPER in breast cancer. J Clin Invest. 2015;125(5):2123-35. https://doi.org/10.1172/JCl79573.

104. Xu S, Zhu L, Liu Y, Wang X, Zhong Y, Su Y, et al. MPP, inhibitor of estrogen receptor $a$, affects YAP nuclear localization during mouse blastocyst formation and in Trophoblast Stem Cells. Chin J Histochem Cytochem. 2019;28(01):6-13. https://doi.org/10.16705/j.cnki.1004-1850.2019.01. 002.

105. Chen W, Bai Y, Patel C, Geng F. Autophagy promotes triple negative breast cancer metastasis via YAP nuclear localization. Biochem Biophys Res Commun. 2019;520(2):263-8. https://doi.org/10.1016/j.bbrc.2019. 09.133.

106. Feng $X$, Zhang M, Wang B, Zhou C, Mu Y, Li J, et al. CRABP2 regulates invasion and metastasis of breast cancer through hippo pathway dependent on ER status. J Exp Clin Cancer Res. 2019;38(1). https://doi. org/10.1186/s13046-019-1345-2.

107. Tufail R, Jorda M, Zhao W, Reis I, Nawaz Z. Loss of Yes-associated protein (YAP) expression is associated with estrogen and progesterone receptors negativity in invasive breast carcinomas. Breast Cancer Res Treat. 2012;131(3):743-50. https://doi.org/10.1007/s10549-011-1435-0.

108. Zheng $X$, Han H, Liu GP, Ma YX, Pan RL, Sang LJ, et al. LncRNA wires up Hippo and Hedgehog signaling to reprogramme glucose metabolism. EMBO J. 2017;36(22):3325-35. https://doi.org/10.15252/embj.20179 7609.

109. Li J, Feng X, Li C, Liu J, Li P, Wang R, et al. Downregulation of WW domain-containing oxidoreductase leads to tamoxifen-resistance by the inactivation of Hippo signaling. Exp Biol Med (Maywood). 2019;244(12):972-82. https://doi.org/10.1177/1535370219854678.

110. Wu X, Zhang $X$, Yu L, Zhang C, Ye L, Ren D, et al. Zinc finger protein 367 promotes metastasis by inhibiting the Hippo pathway in breast cancer. Oncogene. 2020;39(12):2568-82. https://doi.org/10.1038/ s41388-020-1166-y.

111. Li L, Liu T, Li Y, Wu C, Luo K, Yin Y, et al. The deubiquitinase USP9X promotes tumor cell survival and confers chemoresistance through YAP1 stabilization. Oncogene. 2018;37(18):2422-31. https://doi.org/10.1038/ s41388-018-0134-2.

112. Dethlefsen C, Hansen LS, Lillelund C, Andersen C, Gehl J, Christensen $\mathrm{JF}$, et al. Exercise-induced catecholamines activate the Hippo tumor suppressor pathway to reduce risks of breast cancer development. Cancer Res. 2017;77(18):4894-904. https://doi.org/10.1158/0008-5472. Can-16-3125.

113. Lehmann W, Mossmann D, Kleemann J, Mock K, Meisinger C, Brummer T, et al. ZEB1 turns into a transcriptional activator by interacting with YAP1 in aggressive cancer types. Nat Commun. 2016;7:10498. https:// doi.org/10.1038/ncomms 10498 .
114. Zheng L, Xiang C, Li X, Guo Q, Gao L, Ni H, et al. STARD13-correlated ceRNA network-directed inhibition on YAP/TAZ activity suppresses stemness of breast cancer via co-regulating Hippo and Rho-GTPase/Factin signaling. J Hematol Oncol. 2018;11(1):72. https://doi.org/10.1186/ s13045-018-0613-5.

115. Zhu Q, Li J, Wu Q, Cheng Y, Zheng H, Zhan T, et al. Linc-OIP5 in the breast cancer cells regulates angiogenesis of human umbilical vein endothelial cells through YAP1/Notch/NRP1 signaling circuit at a tumor microenvironment. Biol Res. 2020;53(1):5. https://doi.org/10.1186/ s40659-020-0273-0.

116. Samanta S, Guru S, Elaimy AL, Amante JJ, Ou J, Yu J, et al. IMP3 stabilization of WNT5B mRNA facilitates TAZ activation in breast cancer. Cell Rep. 2018;23(9):2559-67. https://doi.org/10.1016/j.celrep.2018.04.113.

117. Alam M, Bouillez A, Tagde A, Ahmad R, Rajabi H, Maeda T, et al. MUC1-C represses the crumbs complex polarity factor CRB3 and downregulates the Hippo pathway. Mol Cancer Res. 2016;14(12):1266-76. https://doi. org/10.1158/1541-7786.Mcr-16-0233.

118. Lim SK, Lu SY, Kang SA, Tan HJ, Li Z, Adrian Wee ZN, et al. Wnt signaling promotes breast cancer by blocking ITCH-mediated degradation of YAP/TAZ transcriptional coactivator WBP2. Cancer Res. 2016;76(21):6278-89. https://doi.org/10.1158/0008-5472.CAN-15-3537.

119. Song $H$, Wu T, Xie D, Li D, Hua K, Hu J, et al. WBP2 downregulation inhibits proliferation by blocking YAP transcription and the EGFR/PI3K/ Akt signaling pathway in triple negative breast cancer. Cell Physiol Biochem. 2018;48(5):1968-82. https://doi.org/10.1159/000492520.

120. Zhao Y, Montminy T, Azad T, Lightbody E, Hao Y, SenGupta S, et al. PI3K positively regulates YAP and TAZ in mammary tumorigenesis through multiple signaling pathways. Mol Cancer Res. 2018;16(6):1046-58. https://doi.org/10.1158/1541-7786.MCR-17-0593.

121. Yu S, Zhang M, Huang L, Ma Z, Gong X, Liu W, et al. ERK1 indicates good prognosis and inhibits breast cancer progression by suppressing YAP1 signaling. Aging (Albany NY). 2019;1 1(24):12295-314. https://doi.org/ 10.18632/aging.102572.

122. Zhu Q, Le Scolan E, Jahchan N, Ji X, Xu A, Luo K. SnoN antagonizes the Hippo kinase complex to promote TAZ signaling during breast carcinogenesis. Dev Cell. 2016;37(5):399-412. https://doi.org/10.1016/j.devcel. 2016.05.002.

123. Ma B, Cheng H, Gao R, Mu C, Chen L, Wu S, et al. Zyxin-Siah2-Lats2 axis mediates cooperation between Hippo and TGF-beta signalling pathways. Nat Commun. 2016;7:11123. https://doi.org/10.1038/ncomm S11123.

124. Mota MSV, Jackson WP, Bailey SK, Vayalil P, Landar A, Rostas JW, et al. Deficiency of tumor suppressor Merlin facilitates metabolic adaptation by co-operative engagement of SMAD-Hippo signaling in breast cancer. Carcinogenesis. 2018;39(9):1 165-75. https://doi.org/10.1093/ carcin/bgy078.

125. Rashidian J, Le Scolan E, Ji X, Zhu Q, Mulvihill MM, Nomura D, et al. Ski regulates Hippo and TAZ signaling to suppress breast cancer progression. Sci Signal. 2015;8(363):ra14. https://doi.org/10.1126/scisignal. 2005735.

126. Vici P, Mottolese M, Pizzuti L, Barba M, Sperati F, Terrenato I, et al. The Hippo transducer TAZ as a biomarker of pathological complete response in HER2-positive breast cancer patients treated with trastuzumab-based neoadjuvant therapy. Oncotarget. 2014;5(20):9619-25. https://doi.org/10.18632/oncotarget.2449.

127. González-Alonso P, Zazo S, Martín-Aparicio E, Luque M, Chamizo C, Sanz-Álvarez M, et al. The Hippo pathway transducers YAP1/TEAD induce acquired resistance to trastuzumab in HER2-positive breast cancer. Cancers (Basel). 2020;12(5):1108. https://doi.org/10.3390/cance rs12051108.

128. Lin CH, Pelissier FA, Zhang H, Lakins J, Weaver VM, Park C, et al. Microenvironment rigidity modulates responses to the HER2 receptor tyrosine kinase inhibitor lapatinib via YAP and TAZ transcription factors. Mol Biol Cell. 2015;26(22):3946-53. https://doi.org/10.1091/mbc.E15-07-0456.

129. Azad T, Nouri K, Janse van Rensburg HJ, Maritan SM, Wu L, Hao Y, et al. A gain-of-functional screen identifies the Hippo pathway as a central mediator of receptor tyrosine kinases during tumorigenesis. Oncogene, 2020;39(2):334-55. https://doi.org/10.1038/s41388-019-0988-y.

130. Turunen SP, von Nandelstadh P, Ohman T, Gucciardo E, SeashoreLudlow B, Martins B, et al. FGFR4 phosphorylates MST1 to confer breast 
cancer cells resistance to MST1/2-dependent apoptosis. Cell Death Differ. 2019;26(12):2577-93. https://doi.org/10.1038/s41418-019-0321-x.

131. Rigiracciolo DC, Nohata N, Lappano R, Cirillo F, Talia M, Scordamaglia D, et al. IGF-1/IGF-1R/FAK/YAP transduction signaling prompts growth effects in triple-negative breast cancer (TNBC) cells. Cells. 2020;9(4):1010. https://doi.org/10.3390/cells9041010.

132. Wu L, Yang X. Targeting the Hippo pathway for breast cancer therapy. Cancers (Basel). 2018;10(11):422. https://doi.org/10.3390/cancers101 10422.

133. Huang $R$, Li J, Pan F, Zhang B, Yao Y. The activation of GPER inhibits cells proliferation, invasion and EMT of triple-negative breast cancer via CD151/miR-199a-3p bio-axis. Am J Transl Res. 2020;12(1):32-44.

134. Mayoral-Varo V, Calcabrini A, Sánchez-Bailón MP, Martín-Pérez J. miR205 inhibits stem cell renewal in SUM159PT breast cancer cells. PLoS ONE. 2017;12(11):e0188637. https://doi.org/10.1371/journal.pone.0188637.

135. Zhang KJ, Hu Y, Luo N, Li X, Chen FY, Yuan JQ, et al. miR-574-5p attenuates proliferation, migration and EMT in triple-negative breast cancer cells by targeting BCL11A and SOX2 to inhibit the SKIL/TAZ/CTGF axis. Int J Oncol. 2020;56(5):1240-51. https://doi.org/10.3892/ijo.2020.4995.

136. Liu Y, Li M, Yu H, Piao H. IncRNA CYTOR promotes tamoxifen resistance inbreast cancer cells via sponging miR-125a-5p. Int J Mol Med. 2019:45(2):497-509. https://doi.org/10.3892/ijmm.2019.4428.

137. Manavalan TT, Teng Y, Litchfield LM, Muluhngwi P, Al-Rayyan N, Klinge CM. Reduced expression of miR-200 family members contributes to antiestrogen resistance in LY2 human breast cancer cells. PLoS ONE. 2013;8(4):e62334. https://doi.org/10.1371/journal.pone.0062334.

138. Liu L, Shen W, Zhu Z, Lin J, Fang Q, Ruan Y, et al. Combined inhibition of EGFR and c-ABL suppresses the growth of fulvestrant-resistant breast cancer cells through miR-375-autophagy axis. Biochem Biophys Res Commun. 2018;498(3):559-65. https://doi.org/10.1016/j.bbrc.2018.03.019.

139. Lu Y, Roy S, Nuovo G, Ramaswamy B, Miller T, Shapiro C, et al. AntimicroRNA-222 (anti-miR-222) and -181B suppress growth of tamoxifenresistant xenografts in mouse by targeting TIMP3 protein and modulating mitogenic signal. J Biol Chem. 2011;286(49):42292-302. https://doi. org/10.1074/jbc.M111.270926.

140. Sorrentino G, Ruggeri N, Specchia V, Cordenonsi M, Mano M, Dupont S, et al. Metabolic control of YAP and TAZ by the mevalonate pathway. Nat Cell Biol. 2014;16(4):357-66. https://doi.org/10.1038/ncb2936.

141. Liu J, Li J, Chen H, Wang R, Li P, Miao Y, et al. Metformin suppresses proliferation and invasion of drug-resistant breast cancer cells by activation of the Hippo pathway. J Cell Mol Med. 2020;24(10):5786-96. https://doi. org/10.1111/jcmm.15241.

142. Wu D, Jia H, Zhang Z, Li S. Circ_0000511 accelerates the proliferation, migration and invasion, and restrains the apoptosis of breast cancer cells through the miR-326/TAZ axis. Int J Oncol. 2021;58(4):1. https://doi. org/10.3892/ijo.2021.5181.

143. Liu Y, Zhang Q, Wu J, Zhang H, Li X, Zheng Z, et al. Long non-coding RNA A2M-AS1 promotes breast cancer progression by sponging microRNA-146b to Upregulate MUC19. Int J Gen Med. 2020;13:1305-16. https://doi.org/10.2147/ijgm.S278564.

144. Hu J, Ji C, Hua K, Wang X, Deng X, Li J, et al. Hsa_circ_0091074 regulates TAZ expression via microRNA-1297 in triple negative breast cancer cells. Int J Oncol. 2020;56(5):1314-26. https://doi.org/10.3892/ijo.2020.5000.

145. Geng Z, Wang W, Chen H, Mao J, Li Z, Zhou J. Circ_0001667 promotes breast cancer cell proliferation and survival via Hippo signal pathway by regulating TAZ. Cell Biosci. 2019;9:104. https://doi.org/10.1186/ s13578-019-0359-y.

146. Liu Y, Li M, Yu H, Piao H. InCRNA CYTOR promotes tamoxifen resistance in breast cancer cells via sponging miR-125a-5p. Int J Mol Med. 2020:45(2):497-509. https://doi.org/10.3892/ijmm.2019.4428.

147. Qiao K, Ning S, Wan L, Wu H, Wang Q, Zhang X, et al. LINC00673 is activated by YY1 and promotes the proliferation of breast cancer cells via the miR-515-5p/MARK4/Hippo signaling pathway. J Exp Clin Cancer Res. 2019;38(1):418. https://doi.org/10.1186/s13046-019-1421-7.

148. Huang X, Tang F, Weng Z, Zhou M, Zhang Q. MiR-591 functions as tumor suppressor in breast cancer by targeting TCF 4 and inhibits Hippo-YAP/TAZ signaling pathway. Cancer Cell Int. 2019;19:108. https:// doi.org/10.1186/s12935-019-0818-X.

149. Cheng $X$, Chen J, Huang Z. miR-372 promotes breast cancer cell proliferation by directly targeting LATS2. Exp Ther Med. 2018;15(3):2812-7. https://doi.org/10.3892/etm.2018.5761.

150. Zhu HY, Bai WD, Ye XM, Yang AG, Jia LT. Long non-coding RNA UCA1 desensitizes breast cancer cells to trastuzumab by impeding miR-18a repression of Yes-associated protein 1. Biochem Biophys Res Commun. 2018;496(4):1308-13. https://doi.org/10.1016/j.bbrc.2018.02.006.

151. Xie D, Song H, Wu T, Li D, Hua K, Xu H, et al. MicroRNA-424 serves an anti-oncogenic role by targeting cyclin-dependent kinase 1 in breast cancer cells. Oncol Rep. 2018;40(6):3416-26. https://doi.org/10.3892/or. 2018.6741.

152. Hua K, Jin J, Zhao J, Song J, Song H, Li D, et al. miR-135b, upregulated in breast cancer, promotes cell growth and disrupts the cell cycle by regulating LATS2. Int J Oncol. 2016;48(5):1997-2006. https://doi.org/10. 3892/ijo.2016.3405.

153. Hua K, Yang W, Song H, Song J, Wei C, Li D, et al. Up-regulation of miR506 inhibits cell growth and disrupt the cell cycle by targeting YAP in breast cancer cells. Int J Clin Exp Med. 2015;8(8):12018-27.

154. Beillard E, Ong SC, Giannakakis A, Guccione E, Vardy LA, Voorhoeve PM. miR-Sens-a retroviral dual-luciferase reporter to detect microRNA activity in primary cells. RNA. 2012;18(5):1091-100. https://doi.org/10. 1261/rna.031831.111.

155. Fang L, Du WW, Yang W, Rutnam ZJ, Peng C, Li H, et al. MiR-93 enhances angiogenesis and metastasis by targeting LATS2. Cell Cycle. 2012:11(23):4352-65. https://doi.org/10.4161/cc.22670.

156. Yu SJ, Hu JY, Kuang XY, Luo JM, Hou YF, Di GH, et al. MicroRNA-200a promotes anoikis resistance and metastasis by targeting YAP1 in human breast cancer. Clin Cancer Res. 2013;19(6):1389-99. https://doi.org/10. 1158/1078-0432.CCR-12-1959.

157. Gao L, Bao Z, Deng H, Li X, Li J, Rong Z, et al. The beneficial androgenic action of steroidal aromatase inactivators in estrogen-dependent breast cancer after failure of nonsteroidal drugs. Cell Death Dis. 2019;10(7):494. https://doi.org/10.1038/s41419-019-1724-9.

\section{Publisher's Note}

Springer Nature remains neutral with regard to jurisdictional claims in published maps and institutional affiliations.

Ready to submit your research? Choose BMC and benefit from:

- fast, convenient online submission

- thorough peer review by experienced researchers in your field

- rapid publication on acceptance

- support for research data, including large and complex data types

- gold Open Access which fosters wider collaboration and increased citations

- maximum visibility for your research: over $100 \mathrm{M}$ website views per year

At BMC, research is always in progress.

Learn more biomedcentral.com/submissions 